San Jose State University

SJSU ScholarWorks

Master's Theses

Master's Theses and Graduate Research

Fall 2015

\title{
Factors Affecting Western Snowy Plover Winter Foraging Habitat Selection in San Francisco Bay Ponds
}

Benjamin Gabriel Pearl

San Jose State University

Follow this and additional works at: https://scholarworks.sjsu.edu/etd_theses

\section{Recommended Citation}

Pearl, Benjamin Gabriel, "Factors Affecting Western Snowy Plover Winter Foraging Habitat Selection in San Francisco Bay Ponds" (2015). Master's Theses. 4661.

DOI: https://doi.org/10.31979/etd.g49s-rk9f

https://scholarworks.sjsu.edu/etd_theses/4661

This Thesis is brought to you for free and open access by the Master's Theses and Graduate Research at SJSU ScholarWorks. It has been accepted for inclusion in Master's Theses by an authorized administrator of SJSU ScholarWorks. For more information, please contact scholarworks@sjsu.edu. 


\title{
FACTORS AFFECTING WESTERN SNOWY PLOVER WINTER FORAGING
} HABITAT SELECTION IN SAN FRANCISCO BAY PONDS

\author{
A Thesis \\ Presented to \\ The Faculty of the Department of Environmental Studies \\ San Jose Staté University \\ In Partial Fulfillment \\ of the Requirements for the Degree \\ Master of Science
}

By

Benjamin G. Pearl

December 2015 
(C) 2015

Benjamin Gabriel Pearl

ALL RIGHTS RESERVED 
The designated Thesis Committee Approves the Thesis Titled

\section{FACTORS AFFECTING WESTERN SNOWY PLOVER WINTER FORAGING} HABITAT SELECTION IN SAN FRANCISCO BAY PONDS

By

Benjamin G. Pearl

APPROVED FOR THE DEPARTMENT OF ENVIRONMENTAL STUDIES

SAN JOSÉ STATE UNIVERSITY

December 2015

Dr. Lynne Trulio Department of Environmental Studies

Dr. Rachel O’Malley Department of Environmental Studies

Dr. Catherine Burns The Nature Conservancy 


\title{
ABSTRACT \\ FACTORS AFFECTING WESTERN SNOWY PLOVER WINTER FORAGING HABITAT SELECTION IN SAN FRANCISCO BAY PONDS
}

\author{
by Benjamin G. Pearl
}

Within the San Francisco Bay Area, Western Snowy Plovers (Alexandrinus nivosus nivosus) nest and winter in former salt ponds. They face a number of threats including human-altered habitats and high levels of predation by mesopredators and raptors. The South Bay Salt Pond Restoration Project (the Project) is a large wetland restoration project that will change and potentially eliminate Snowy Plover habitat in the region. As the Project returns salt ponds to tidal wetland, there will be less of the dry, flat, and sparsely vegetated habitat that plovers need for breeding and wintering habitat. A greater understanding of the specific microhabitat requirements for high quality plover foraging sites is needed. In particular, it is important for managers to understand what constitutes high quality wintering habitat for Snowy Plover numbers. This study assessed the characteristics at sites where Snowy Plovers winter in former salt ponds, especially habitat traits related to promoting plover foraging. Analysis of plover foraging habitat showed that plovers were associated with increasing plant height, water cover, and distance from perches and levees. This information is designed to inform restoration and management decisions in efforts to meet Snowy Plover recovery goals in the South San Francisco Bay. 


\section{ACKNOWLEDGEMENTS}

This Masters project would not have been possible without the help and guidance of many people. I owe a great debt of gratitude to my family. My parents always stressed the importance of academic excellence, constantly pushing me to produce my finest work. My siblings Jacob and Rachel were my role models growing up, setting an example for me to follow throughout my educational career. My fiancé Erica Goldsworthy provided a tremendous amount of love and support while I worked on completing my degree, allowing me to focus much of my time and energy on my work.

My professors at San Jose State University were instrumental in the quality and focus of this project. My thesis advisor Dr. Lynne Trulio was a guiding voice of knowledge and wisdom throughout. Her advising greatly improved the quality of this thesis throughout. Dr. Rachel O'Malley provided early instruction on field methods, and later gave valuable advice concerning invertebrate trapping, identification, and analysis.

Lastly, I would like to thank everyone at San Francisco Bay Bird Observatory (SFBBO) for the various ways in which they assisted in my professional and academic growth. Dr. Cat Burns hired me at SFBBO as an intern for the 2013 Snowy Plover breeding season and Snowy Plover biologist during the 2014-2015 breeding seasons. She provided excellent technical knowledge on plover population dynamics and theory that greatly improved the scientific background of this work. Karine Tokatlian, my manager and trainer while at SFBBO, played an especially critical role. Her mentoring and guidance allowed me to become a well rounded, yet highly specialized field worker, without which I would not have been able to conduct the field work for this project. 


\section{TABLE OF CONTENTS}

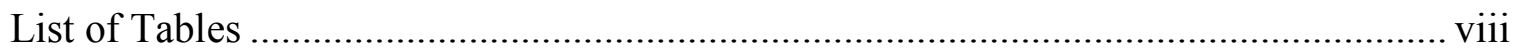

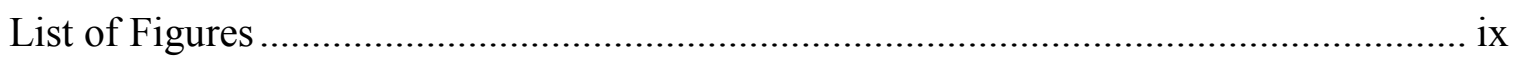

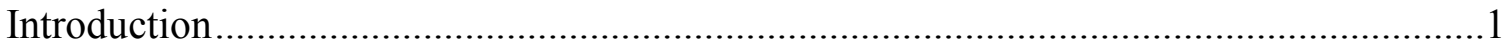

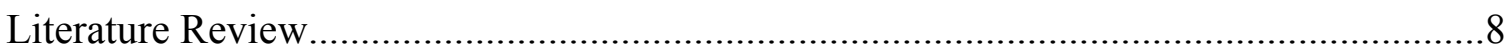

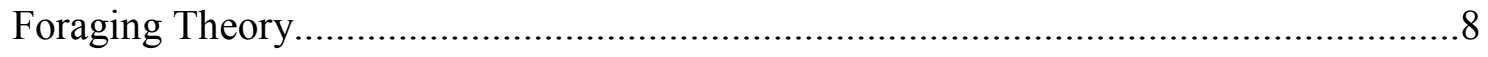

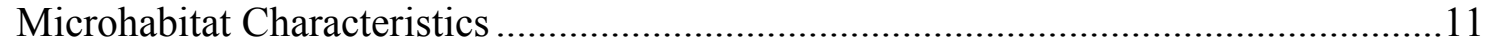

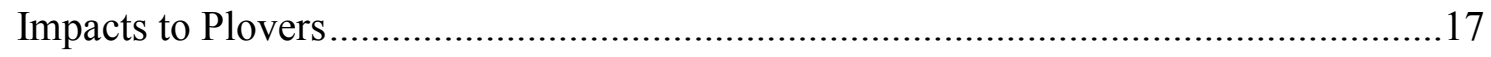

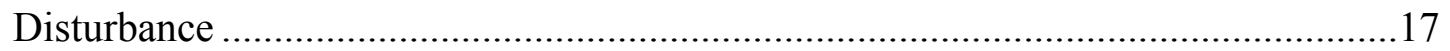

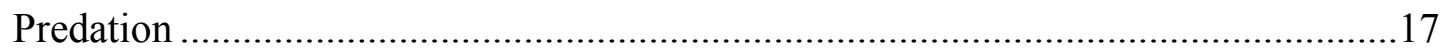

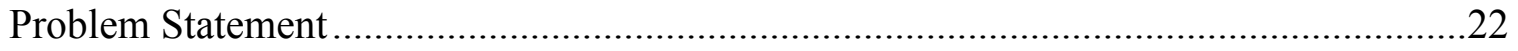

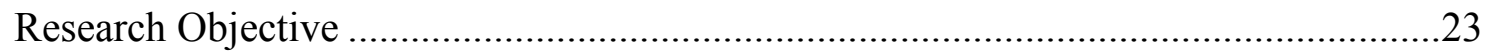

Research Questions and Hypotheses .........................................................................23

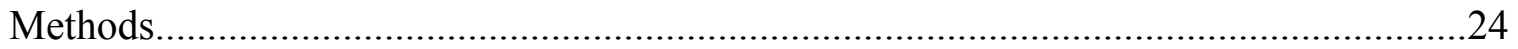

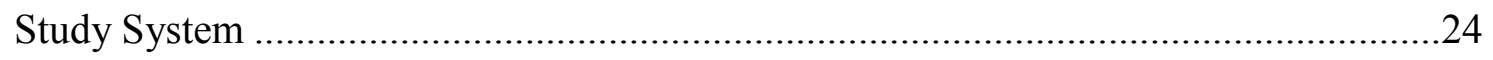

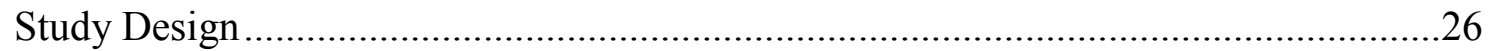

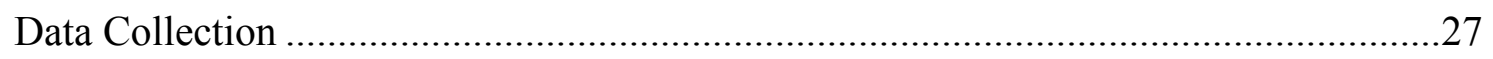

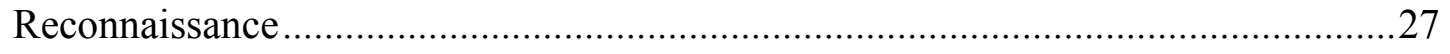

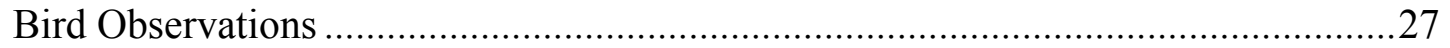

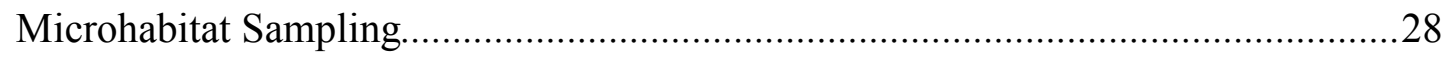

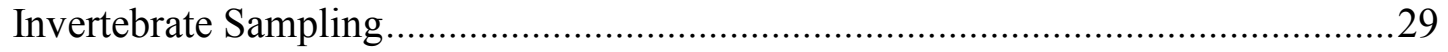

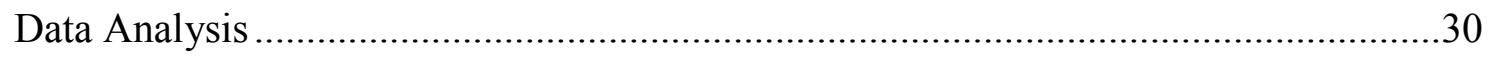




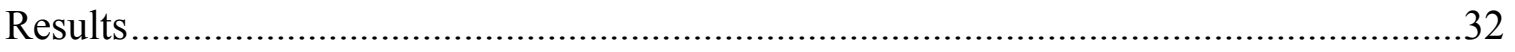

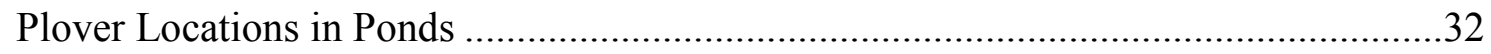

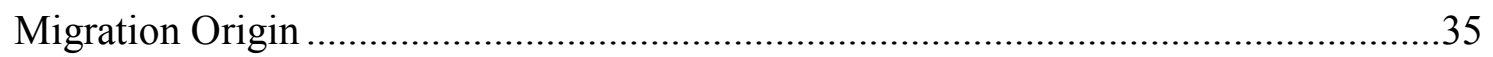

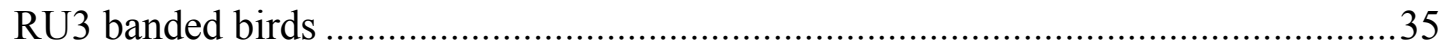

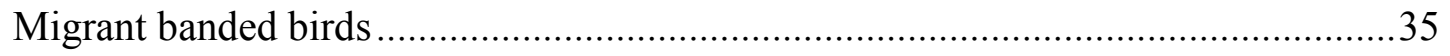

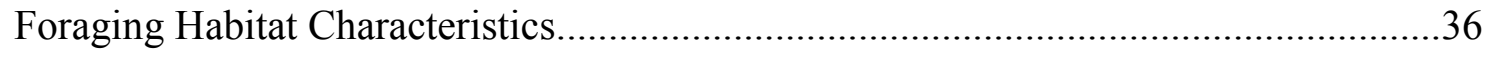

$\mathrm{H}_{0} 1$

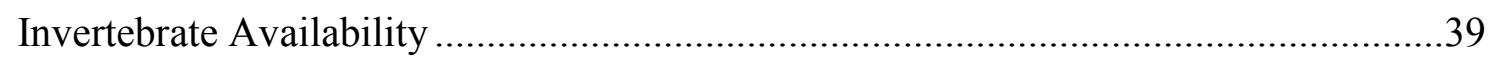

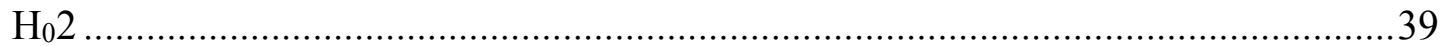

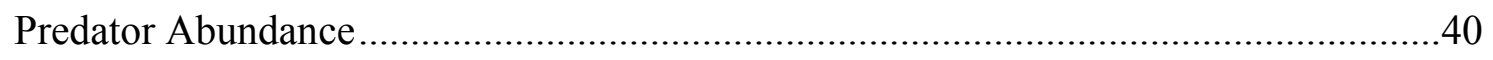

$\mathrm{H}_{0} 3$

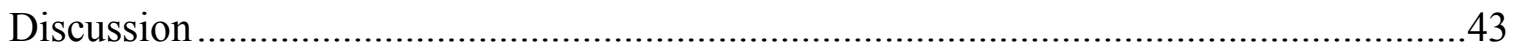

Associated Habitat Characteristics ………………………........................................

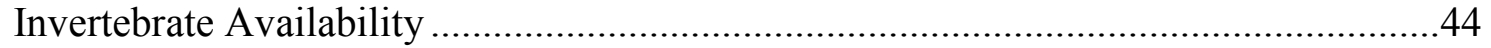

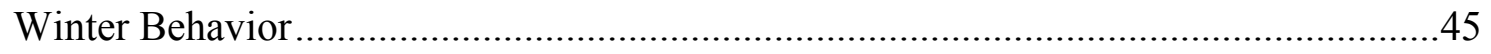

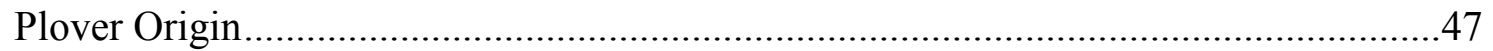

Management and Conservation Implications................................................................

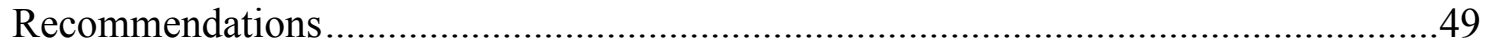

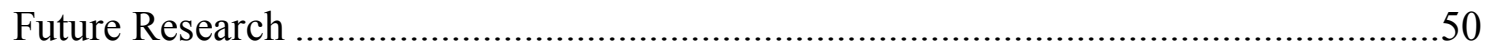

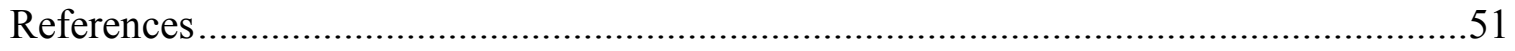

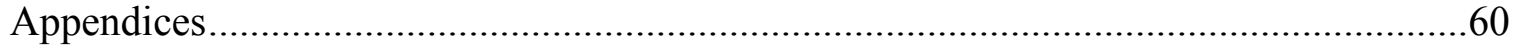




\section{LIST OF TABLES}

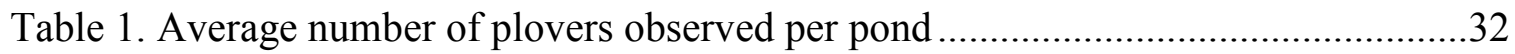

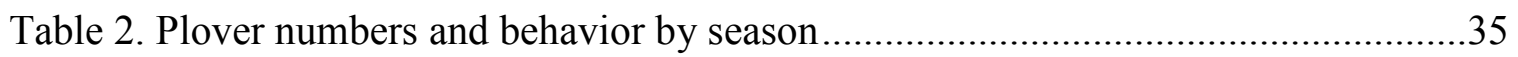

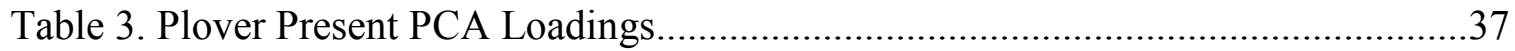

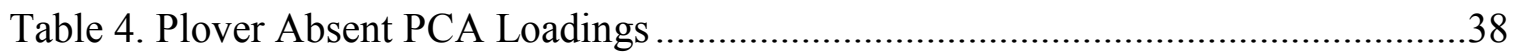

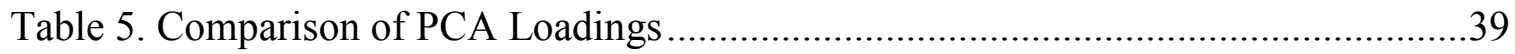

Table 6. 2013-2014 total predator sightings by species and pond ................................40

Table 7. 2014-2014 total predator sightings by species and pond ................................41 


\section{LIST OF FIGURES}

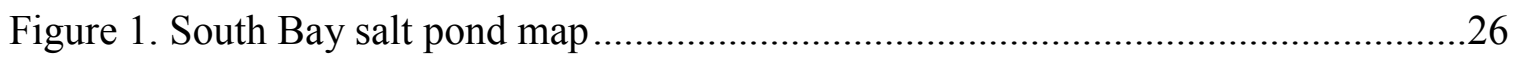

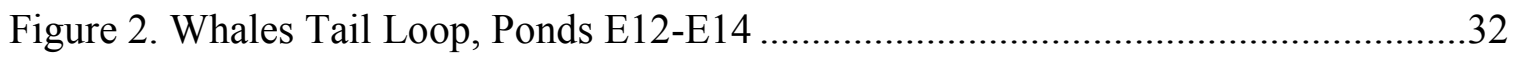

Figure 3. Old Alameda Creek Loop, Ponds E6A, E6B, E8 ………………......................33

Figure 4. Mount Eden Creek Loop, Ponds E11, E16B, E15B, E14B.................................33

Figure 5. Ravenswood Complex, Ponds R1-5, RSF2 ……………………....................

Figure 6. Warm Springs Complex, Ponds A22-23 …………….....................................

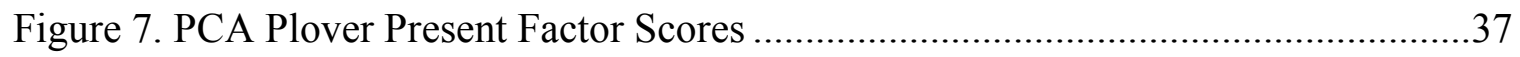

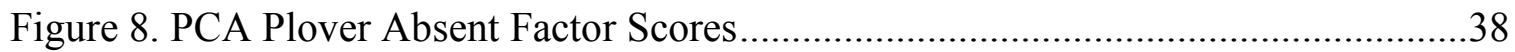




\section{Introduction}

Shorebird species have experienced significant declines over the past 150 years, coinciding with extensive loss of breeding and wintering habitats in coastal and inland wetlands (Howe, 1987). In particular, anthropogenic changes to wetlands, including landfill, waterway diversion, dredging, and diking all have caused significant impacts to sensitive wetlands (Hartig et al, 2002; Howe, 1987). Wetlands include various components that provide habitat for millions of birds. These include subtidal wetlands, which remain submerged and provide deep water foraging habitat, as well as intertidal wetlands, which are exposed twice daily coinciding with the tides. Intertidal wetlands can further be broken up into tidal flats, large unvegetated mudflats that provide significant foraging habitat for wintering and breeding shorebirds, and tidal marsh, usually densely vegetated areas that provide roosting, breeding, and foraging habitat for numerous bird species.

In California, there are currently a total of approximately 154,128 ha of intertidal and subtidal wetlands, including 34,688 ha of tidal flat and 33,153 ha of marsh (Solek et. al, 2011). Prior to colonization of California by Europeans, the San Francisco Bay Area (Bay Area) alone contained 220,000 ha of tidal wetlands, containing large areas of tidal flats, brackish marsh, and over 80,000 ha of salt marsh (Williams \& Faber, 2001). The tidal flats and marshes supported large flocks of seabirds and shorebirds, abundant sea life, and healthy populations of apex predators to keep balance within the ecosystem. By 1972, more than $90 \%$ of the original wetlands of the Bay Area had been diked, filled, and developed for various purposes (Williams \& Faber, 2001). This reduction in total 
available habitat for shorebirds and seabirds has increased interspecific and intraspecific competition for foraging, roosting, and nesting habitat, contributing to the decline in shorebirds (Galbrath et al, 2002).

The Western Snowy Plover (Charadrius nivosus nivosus) (plover) is one species that has suffered significantly from habitat loss and disturbance. Plovers are found along the Pacific Coast, with populations in California, Oregon, Washington, and Baja California, Mexico (USFWS, 2012). They are among the smaller shorebird species, averaging around 15-17 $\mathrm{cm}$ in length and weighing between 34-58 $\mathrm{g}$ (Page et al., 2009). Male and female non-breeding plumage is similar, with light brown upper, white breast, belly, and hind neck collar, breast band restricted to lateral patches, and black legs (Page et al., 2009). During breeding season, males are distinguished by presence of a rusty cap at the beginning of the season, as well as dark ear coverts, black crown, and foreneck patches (Page et al., 2009). Plovers are rare in that they use a facultative polygamous mating system in which females often desert their first brood of the season to renest with another mate (Page et al., 2009). Clutches are typically two to three eggs, with three the most common, though four egg clutches do occasionally occur. The frequency of two egg clutches tend to increase later in the season as overall energy levels in breeding females dissipate. Chicks are precocial, having the ability to run and forage for themselves within hours after hatching, and fledge after approximately 31 days.

Plovers have been federally listed as threatened since 1993, and they are listed in California as a species of special concern (USFWS, 2012; California Department of Fish \& Wildlife, 2010). Between 2004 and 2014, the range-wide population has fluctuated 
between 1,537 and 1,877 adults (Hudgens et al., 2014). The US Fish and Wildlife Service (USFWS) wrote a plover recovery plan in 2007 with range-wide as well as regional goals based upon six geographic regions, called recovery units. The goal for Recovery Unit 3 (RU3), which includes the San Francisco Bay, is 250 breeding pairs, but conservation efforts to date have been unable to meet this goal (USFWS, 2012). Between 2003 and 2014, breeding window surveys, which are used to assess the current breeding population for the recovery unit, averaged $163.6 \pm 62.0$ birds, at most amounting to slightly less than half of the goal (SFBBO, 2003-2014). Winter window surveys averaged slightly higher counts due to the presence of winter migrants from the inland population and across the pacific range, which over the same time have averaged 181.8 \pm 98.5 birds (SFBBO, 2003-2014). Another metric used to assess the recovery of plovers is fledge rate per male, with a goal of one fledge per male set as the threshold for plovers to be at a sustainable level. This metric is tough to assess in RU3 due to the limitations on banding rates caused by the size and varied terrain of the ponds. One calculation of the fledge rate per male for the 2010 breeding season yielded 0.62 fledged chicks per male however, well short of the goal (SFBBO, 2010).

The South Bay Salt Pond Restoration Project (the Project), encompassing over 6,070 hectares of former salt production ponds, is the largest wetland restoration project on the West Coast. The Project has set its own recovery goals, aiming to support 250 breeding birds within the project area (South Bay Salt Pond Restoration Project, 2007). The Project aims to achieve this goal through adaptive management via careful restoration of former salt production ponds. However, as the Project returns former salt 
ponds to tidal marsh, Snowy Plover habitat will be lost. The exact amount of habitat lost will depend upon how much of the ponds are restored. The project has a range of end points for the amount of habitat that will be restored, ranging from $90 \%$ restored to $50 \%$ restored. Plovers generally have a maximum nest density of six nests per ha, with a maximum recorded in California at 20 nests per ha (Page, Stenzel, Winkler, \& Swarth, 1983). Thus, areas restored for plover habitat must maximize efficacy in order to achieve the Project and RU3 recovery goals.

The key to successful restoration begins with field data that accurately depict the dynamic conditions of wildlife and the environment. The San Francisco Bay Bird Observatory (SFBBO) monitors the number of plovers, location of nests, and their breeding success within the Restoration Project area. From 2008 through 2012, the number of nests and hatch rate has fluctuated greatly within the project area and RU3 as a whole, with no clear overall trend. The greatest number of nests was 243 nests in 2010 , while the lowest was 118 in 2008 (mean nest number was 177.0 per year) (SFBBO, 2008-2013). Hatching rate was highest during 2013 at 64.2\%, and lowest during 2010 at 41.1\%, with an average of 93.2 nests per year hatching chicks (SFBBO, 2008-2013.)

Within the San Francisco bay area, plovers mainly utilize salt panne habitat for nesting and foraging, as well as occasional use of levees, pond edges, and small islands built by the SBSPRP specifically for shorebird habitat. An unfortunate side effect of tidal restoration of salt production ponds is the extensive loss of salt panne habitat that plovers rely upon. Due to the lack of suitable habitat in the Bay Area and nest density limits for 
plovers, it is doubtful that the 250 breeding pair goal will be reached without extensive habitat restoration and enhancement for plover nesting habitat.

In addition to the potential loss of available habitat, plover populations are threatened by increased predation. Within the Bay Area, red-tailed hawks (Circus cyaneus), northern harriers (Buteo jamaicensis), and peregrine falcons (Falco peregrinus) have been identified as significant predators of plover adults, chicks, and eggs (Demers \& Robinson-Nilsen, 2012). These raptor populations, which had previously dropped precipitously due to heavy pesticide use from the 1940s through the 1960s, have recovered significantly in recent years, posing an increasing threat to wintering and breeding plovers. Furthermore, the absence of apex predators within the ecosystem has allowed mesopredators such as corvids, gulls, and foxes, which are common nest predators, to expand their populations, putting increasing stress on sensitive shorebird species such as plovers (Crooks \& Soule, 1999). These mesopredators are known as synanthropic species, defined as the ability to thrive in the presence of humans in numbers not normally observed in nature (Shochat et al., 2010).

California gulls (Larus californicus) are an especially significant threat to plovers in the Bay Area. Over the past 100 years, this gull species has undergone exponential growth in population size and expansion in its breeding distribution. Historically, California gulls were only winter visitors to San Francisco Bay, and did not breed along the Pacific coast (Conover \& Conover, 1981). In 1981, coinciding with severe anthropogenic change to the largest breeding colony in California located at Mono Lake, this species began breeding in the Bay Area (Wrege et al., 2006; Strong et al., 2004). By 
2003, there were seven colonies located within the Bay Area. The breeding population increased from 412 birds in 1982 to over 48,000 birds in 2015 (SFBBO, unpub).

California gulls have been identified as a significant predator for plovers within Recovery Unit 3 (Demers \& Robinson-Nilsen, 2012). Gulls also use similar habitat to plovers for foraging, roosting, and breeding, further restricting the available habitat for plovers. As California gulls expand their range and occupy a greater amount of suitable shorebird habitat, they pose an increasing threat to the recovery of plovers in the Bay Area. In many parts of the plover's range, direct human disturbance is also a major impediment to recovery. At Devereux Slough, a public beach near Santa Barbara, CA, the disturbance rate to wintering plovers was measured at 4.3 per hour, as compared to 0.023 per hour at a local protected beach (Lafferty, 2001). The level of disturbance by beach users seen at Devereux Slough is similar to that seen elsewhere in California and a primary reason for plovers abandoning 52 of 80 beach nesting habitats along the Pacific Coast (Page, 1981 as cited in Lafferty, 2001). In other beach breeding habitats, as well as in Bay Area habitat adjacent to trails, human disturbance is similarly high, increasing stress to plovers and negatively affecting habitat use. A study of nesting plovers in the South San Francisco Bay found the average flushing distance of nesting birds to be $145 \mathrm{~m}$ when approached by a trail walker (Trulio, Robinson-Nilsen, Sokale, \& Lafferty, 2012). Additionally, the study found that the longer the disturbance lasted, the longer birds stayed off their nests, putting eggs at risk from predators and temperature changes.

The combined impacts of reduced and degraded overall habitat, increased predation, and high levels of anthropogenic disturbance can result in reduced foraging 
opportunities, poorer overall body condition, and decreased reproductive success for plovers. These circumstances create substantial impacts on wintering populations, greatly reducing the number of individuals that survive to the breeding season (Norris et al., 2004; Saino et al., 2004). Those individuals that do make it to the breeding season may have a reduced ability to breed successfully as a result of the elevated stress incurred during winter, casting further doubt on the future of plover recovery.

Most plover research to date has largely focused upon the breeding season, including nesting plover habitat requirements. Little is known about the needs of wintering plovers however, especially in salt pond habitats. Information on winter habitat selection, time spent foraging, and invertebrate prey species present in wintering plover habitat is essential for managers seeking to help protect wintering birds and prepare them for the breeding season.

This thesis research assessed the importance of several habitat factors in plovers' choices of winter foraging habitat in San Francisco Bay salt ponds by identifying what microhabitat characteristics may be preferred by plovers, how predator presence affects use of foraging habitat, and what prey species are present in the habitat used by plovers. By identifying these characteristics, planners for the SBSPRP and wildlife managers of similar habitats can enhance and restore salt ponds to create better wintering foraging habitats. Effective implementation of these findings may contribute to the USFWS eventually achieving its recovery goals. 


\section{Literature Review}

\section{Foraging Theory}

Foraging plays a central role in the life history of shorebirds. Access to high quality foraging patches is essential for the survival of wintering populations and success of breeding populations. In breeding populations, food availability can affect clutch size and overall fecundity (Martin, 1987), as well as the timing of reproduction (Daan, Dijkstra, Drent \& Meijer, 1988; Zuria \& Melink, 2005). In wintering populations, food availability is essential to build up fat reserves that allow successful migration and assist in thermoregulation during periods of adverse weather (Dugan, Evans, Goodyer \& Davidson, 1981; Lima, 1986;McNamara \& Houston, 1990). During winter, the high energetic demands of thermoregulation and migration require that shorebirds spend a greater amount of time foraging during wintering compared to breeding season (Alves et al., 2014). Research has shown that increased foraging during winter can increase the intensity of raptor predation, resulting in high mortality and greatly reduced breeding populations (Page \& Whitacre, 1975.)

Promoting optimal foraging is a critical strategy for the survival and recovery of shorebird populations. It is essential that birds are able to find and exploit high quality patches due to the uncertainty of foraging, high intraguild competition, and rigorous energetic demands (Alves et al., 2013). The theory of optimal foraging states that animals optimize their foraging strategy by making decisions when to leave a foraging patch based upon prey abundance and quality encountered, probability of finding future prey, and predation risk (Krebs, Ryan, \& Charnov, 1974). This theory has been studied 
extensively in shorebirds, especially in Eurasian oystercatchers, Haematopus ostralegus. Sutherland's (1982) study of cockle-specialist oystercatchers found that they always preferred large size cockles, but would adjust the number of smaller cockles consumed based upon the size of prey encountered (Sutherland, 1982). The oystercatchers optimized their foraging by adjusting to the conditions encountered, thus ensuring they would meet their energetic demands. Another study of oystercatchers, this time looking at mussel (Mytilus edulis) specialists, found that they rarely took the largest or smallest mussels (Meire \& Ervynchk, 1986). When selecting mussels, they preferentially selected for the largest size mussels with thin shells. These mussels were the most profitable prey when factoring in the reward versus the predation risk associated with handling time. Thus, the oystercatchers were foraging in a manner consistent with optimal foraging. Among species that have a more diverse diet, optimal foraging becomes more complex. Goss-Custard (1977) studied redshank, Tringa tetanus, and found these birds preferred large Neries spp. worms to small worms when both were present. When large worms were scarce, redshank would revert to a diet composed mostly of small worms. However, if the amphipod, Corophium volutator, was present, redshank would preferentially forage upon them, leaving aside worms of all size classes in favor of the easier to detect amphipods. Redshank adjusted their diet based upon a combination of the ease of capture and reward of prey, finding the optimal balance that allowed them to maintain a high search speed with profitable results (Goss-Custard, 1977).

Another critical aspect of optimal foraging concerns meal size. Although foraging is important for thermoregulation, migration, and other daily energetic costs, 
over-foraging can increase predation risk due to increased weight and reduced mobility. A laboratory experiment of hummingbirds found that despite being supplied with a surplus of food, hummingbirds never over-ate at a given meal (Debenedicts, Gill, Hainsworth, Pyke, \& Wolf, 1978). Similar foraging times were observed when comparing birds in the laboratory and in the field, demonstrating that moderation in foraging is an instinctual component of bird foraging habits. During winter, shorebirds adhere to this habit, as they must be careful not to increase fat deposition to a level that would impede flight (Metcalfe \& Furness, 1984). However, during pre-migration near the end of winter, shorebirds greatly increase their fat deposition to provide the energy needed for migration and breeding (Metcalfe \& Furness, 1984).

Shorebirds must adjust their foraging technique to balance intake rate and predation risk. A study of foraging lapwings, Vanellus vanellus, and golden plovers, Pluvialis apricaria, found that the two species differed in the amount of time they spent crouching before pecking (Thompson, 1983). Crouching is a behavior associated with increasing the quality of prey caught, but can also reduce vigilance, leading to an increased likelihood of predation. To counter this risk, birds can increase their flock size, reduce the amount of time they spend crouching, or reduce the size of prey they select. The study found that lapwings did not reduce their crouch duration but reduced the size of prey to cut down on handling time, while golden plovers reduced their crouch duration and the depth of their probe to select smaller prey with a shorter handling time (Thompson, 1983). Both species found different ways to optimize their foraging while keeping predation risk at an acceptable level. 
Charnov's marginal value theorem (1974) expands on optimal foraging theory in a patchy environment. When foraging patches are interspersed within areas of no available food, animals will forage within patches until the marginal capture rate within the patch equals the average capture rate for the habitat. The marginal value theorem can help to explain how plovers utilize habitat within the Bay Area. The South San Francisco Bay contains numerous types of wetlands that provide foraging habitat for a diverse array of shorebirds. Although prey species, including terrestrial and marine invertebrates, are abundant in these habitats, plovers are specialized feeders employing a shallow probing technique. Some studies have shown that this foraging technique results in a lower intake rate compared to similar sized birds using other foraging techniques, such as the steady multiple probing technique employed by Calidris species (Goss-Custard, 2006). In addition, plovers appear to be selecting for specific foraging patches, which may require a specific set of microhabitat characteristics related to substrate type, sediment size, and moisture content to provide the appropriate suite of invertebrate prey. Thus, plover foraging habitat is dispersed patchily. Patchy foraging habitat, combined with a slow intake rate, present challenges to plovers as they optimize their foraging.

\section{Microhabitat Characteristics}

Understanding microhabitat characteristics of foraging habitat is critical for the recovery of threatened and endangered species. This information can be used to properly enhance and restore habitat, which will allow species to optimize foraging in both wintering and breeding habitat. Substrate type and sediment size are particularly 
important for shorebird foraging, as they are significant factors for abundance and distribution of invertebrate prey. Colwell and Landrum (1993) studied wintering birds in Humboldt Bay and found that semi-palmated plovers (Charadrius semipalmatus) and ruddy turnstones (Arenaria interpres) were found almost exclusively in terrestrial sites that contained a significant percentage of small-grained sand. Amphipods of the genus Corophium, considered a keystone prey species in estuarine systems, were twice as abundant in sand compared to large-sized cobbles; substrate size explained $22 \%$ of the overall shorebird distribution in this study (Colwell \& Landrum, 1993). Substrate type is an important feature in the life history of some insect larvae. Substratum along estuary beds composed of large particles has been documented as an important characteristic allowing for some species of freshwater flies to develop prior to adulthood (Williams \& Williams, 1998). Areas containing this type of bed substrate can significantly increase insect prey availability for nearby foraging shorebirds. Studies in agricultural grasslands have also documented the importance of substrate types, with bare earth identified as an especially important habitat characteristic for providing invertebrate prey abundance (Perkins et al., 2000).

Prey distribution and abundance may also be influenced by random, transient habitat characteristics such as beach wrack. Brindock and Colwell (2011) found wintering western Snowy Plovers on Humboldt county sandy beaches were positively correlated with brown algae, greater beach width, and low vegetation. Brown algae clumps, which often wash up along the beach after storms, were especially important. Amphipods, burrowing invertebrates, and flies were shown to be associated with the 
location of brown algae clumps (Brindock \& Colwell, 2011). Within the South Bay salt ponds, no brown algae washes onto the shore, as the ponds are closed to tidal action. However, fresh and brackish water algae do grow in some of the ponds and nearby channels. As the water depth and cover changes seasonally, exposed algae may provide a similarly significant source of prey for plovers.

Foraging habitat selection for wintering birds plays a significant role in surviving winter and transitioning to breeding season. In addition to substrate size and composition, common factors that influence foraging site selection include water cover and depth, plant cover and height, prey distribution and density, substrate moisture, and elevation/grade. A study of three habitat types-- vegetation, tidal flat, and water--located at five restored sites at Point Mugu, California, illustrated how habitat characteristics affected shorebird use of a restored wetland. The four taxa studied, marbled godwits (Limosa fedoa), willet (Tringa semipalmata), dowitchers (Limnodromus spp.), and sandpipers (Calidris spp.), showed species-specific preferences based upon habitat characteristics. Willets and dowitchers avoided habitat diversity and tidal flat cover, while godwits and sandpipers were attracted to both characteristics (Armitage, Jensen, Yoon, \& Ambrose, 2007). Percent water cover and creek length were also important, with dowitchers showing a positive correlation with increasing cover and no effect of creek length, sandpipers showing a negative correlation with increasing cover and positive correlation with creek length, and willets and godwits showing no effect from water cover and negative correlation with creek length. Other studies assessing site characteristics among species assemblages have looked at variation in substrate size and 
composition (Quammen, 1982); ground moisture, vegetation cover, and distance to water (Conway, Smith, \& Ray, 2005); length of tideline, tidal flat width, channelization, standing water, timing of tidal ebb, sediment particle size, and substrate heterogeneity (Danufsky \& Colwell, 2003); and wetland area, water depth, percent emergent vegetation, and number of wetlands within 10km (Webb, Smith, Vrtiska, \& Lagrange, 2010).

Some microhabitat characteristics can serve as predictors for foraging site use by small shallow-probing shorebirds. Drake, Thompson, and Drake (2001) studied nonbreeding piping plovers (Charadrius melodus) along Texas shorelines in the Gulf of Mexico, where greater than $50 \%$ of the continental wintering population resides. The study found that plovers used wet substrates $(88 \%)$ significantly more often compared to dry substrates (12\%), and most birds were sighted on algal flats (51\%) and lower sand flats $(23 \%)$. Additionally, use of tidal flats adjacent to developed areas was extremely rare, with only 5 of 1371 sightings located on these flats. Another study of piping plovers, located on the Missouri River, examined habitat preferences between natural, managed, and restored sandbars. The study found that engineered islands that contained open dry sand and pebbles, sparse vegetation, and areas of moist sediment were the most attractive to piping plovers for both nesting and foraging (Catlin, Fraser, Felio, \& Cohen, 2011).

Salt ponds, flats, and pannes can vary seasonally in water depth and cover depending upon fluctuations in precipitation and air temperature. In the San Francisco Bay, many of the ponds are actively managed to control water depth and cover using 
systems of water locks and levees. This management system provides habitat for different types of bird species during winter, migration, and breeding season, leading to temporal variation in habitat availability and influencing patterns of species habitat selection. A study of how temporal habitat variation affected avian communities in the north San Francisco Bay salt ponds found that, during winter, the density of shallowprobing shorebirds (i.e. sandpipers, plovers, and other small shorebirds) was higher in the baylands compared to ponds when the ponds had deeper water levels and less available habitat. (Takekawa, Lu, \& Pratt, 2001.) As the amount of water cover and depth decreased in salt ponds after the rainy season, density of shallow probers shifted towards salt ponds and away from baylands. Overall, shallow probers preferred salt ponds, as these areas had a high percent of low vegetative cover and the greatest cover by shallow water.

Plover habitat across the species' range varies and is influenced by the conditions encountered. In the high plains of west Texas where temperatures are often extreme, Snowy Plovers forage, roost, and breed along saline lakes, often among small rocks, wood debris, and other small objects that provide shade to assist in thermoregulation. Associating with objects can lead to increased rates of predation on plovers, as predators, especially corvids, key in on these objects to locate plovers (Saalfeld, Conway, Haukos, \& Johnson, 2011). At Mono Lake, plovers forage, roost, and nest on rolling sand-pebble ridges along the lake shore and alkali-encrusted sand flat. At these sites, plovers breed in the open, under driftwood, or beside or under tumbleweeds (Page et al., 1981). In northern Humboldt County, plovers inhabit two distinct site types. The most common 
habitat is along flat sandy beaches with sparse vegetation, similar to habitat used throughout the Pacific subspecies range. Less commonly, birds use gravel bars along the Eel River, a distinct habitat among plovers along the Pacific coast that provides several advantages over sandy beach habitat. The larger substrate size along the bars reduces plover tracks and increases crypsis (Colwell et al., 2011). In addition, human activity is ten times lower on the gravel bars than at sandy beaches, reducing the energy spent by plovers in avoiding humans and increasing time spent foraging, roosting, and incubating eggs (Colwell et al., 2010). These factors may have contributed to the greater reproductive success realized at gravel bars compared to sandy beaches; the mean annual fledging success of males on gravel bars from $2001-2006$ was $1.4 \pm 0.4$ versus $0.7 \pm 0.3$ at beach habitats (Colwell et al., 2010). Although gravel bar habitat is considered much higher quality habitat based on the increased reproductive success, there has been a gradual reduction in recent years of use of this habitat due to unknown causes (Colwell et al., 2010).

Gravel bar habitat is similar in many ways to the habitat used within former salt ponds in the San Francisco Bay Area, California. Plovers in the SF Bay Area forage mainly upon small dry islands, salt pannes, and flats within ponds that are multi-textured, containing small crevices, depressions, or raised bumps. All of these habitat characteristics act to increase the crypsis of foraging, breeding, and roosting plovers. Several sites at pond complexes in the South Bay have been restored to provide high quality habitat for plovers. These sites are located at Eden Landing Ecological Reserve (Eden Landing), owned by California Department of Fish and Wildlife (CDFW), and 
Don Edwards San Francisco Bay National Wildlife Refuge (the Refuge), part of the San Francisco Bay National Wildlife Refuge Complex and owned by United States Fish and Wildlife (USFWS). Some of these sites contain broken-up oyster shell, which is meant to further increase crypsis. In 2014, a large amount of oyster shell was spread onto E14 in Eden Landing, the most productive plover pond in the South Bay.

\section{Impacts To Plovers}

Disturbance. Human disturbance along trails at some salt ponds is significant, further reducing the amount of available habitat. Since the South Bay Salt Pond Restoration Project is a dual-purpose project designed to restore native ecosystems while also creating new public bay trails, disturbance is expected to increase in some areas. Although the general foraging habitat characteristics of plovers during the breeding season are known, the habitat and microhabitat characteristics, such as distance to water, percent plant cover, soil moisture, and invertebrate prey density of wintering birds at ponded sites have not been characterized.

Predation. With reduced habitat for foraging, plovers may be forced to assemble in more dense flocks than might be seen with greater habitat availability. While most shorebirds use large flock size to reduce predation risk, plovers are more secretive, often relying on crypsis and low profile to avoid detection by predators (B. Pearl, pers obs). This increased density could reduce the effectiveness of their natural ability to blend in and consequently increase predation risk. Predation is a significant factor affecting the health of wintering and migrating shorebird populations. For example, a study of raptor 
predation at Tyninghame estuary in Scotland was shown to play a major role in the population size of small-bodied shorebird populations. A relatively high number of raptors were present each day and carrion crows (Corvus corone) frequently stole prey items from raptors (kleptoparasitism), causing raptors to kill additional shorebirds (Cresswell \& Whitfield, 1994). For dunlin (Calidris alpine) and redshank (Tringa tetanus), predation was exceptionally high, averaging $12.4 \%$ and $45.6 \%$ of each wintering population over three seasons (Cresswell \& Whitfield, 1994). The Bay Area has experienced a significant recovery in raptors and increase in American crow (Corvus brachyrynchos) and common raven (Corvus corax) populations recently. There is evidence that American crows practice kleptoparasitism on large birds (Kilham, 1984). With no apex predators to control these populations, raptor predation and corvid kleptoparasitism may significantly increase wintering plover mortality. Overwinter predation could result in a smaller breeding population and could have severe impacts on recovery goals for the Bay Area plover population.

Predation risk often depends on where birds choose to forage and in what size flock they assemble. A study of wintering red knots, Calidris canutus, found that adults had a winter survival rate of $88.9 \%$, while juveniles had a winter survival rate of $83.5 \%$ (Van Den Hout, Spaans, \& Piersma, 2008.) The cause of the slightly lower survival rate in juveniles was due to both competition and inexperience. Adults chose to forage in low risk but low reward patches far from shore, which forced juveniles to forage in near shore patches with high risk and reward. In addition, juveniles often fed alone or in small flocks, increasing the likelihood of mortality per individual. Other features of foraging 
habitat, such as plant cover and height, may play a significant role in habitat selection and flocking behavior, as they can greatly influence predation risk. Foraging among vegetation has been shown to significantly increase the risk of predation for small shorebirds, as Dekker and Ydenberg (2003) found in wintering dunlins. These results suggest it is not optimal for plovers to forage in patches containing significant vegetation. However, study is needed to determine if, under some circumstances, plovers may be able to forage among these patches without significantly increasing their predation risk due to their cryptic appearance and behavior.

Migrating and wintering shorebirds are forced to make tradeoffs between lengthof-stay (LOS) at foraging sites and risk of predation. The decline and subsequent recovery of raptor populations resulting from banning pesticide use has provided a unique opportunity to assess how shorebird migration and foraging behavior is affected by predation risk. Increases in raptors may lead to an increase in both lethal and non-lethal predation attempts. Non-lethal predation attempts are defined as events that increase stress and force birds to expend a significant amount of energy evading predation, while not causing direct harm. Non-lethal predation can cause birds to forage in low quality patches, reduce time spent foraging, reduce clutch size, and reduce level of parental investment, all of which can significantly reduce reproductive success (Cresswell, 2008). The effects of non-lethal predation have been documented in migrating western sandpipers (Calidris mauri) along the Pacific coast, where a large increase in peregrine populations resulted in alteration of western sandpiper migration patterns, shortening LOS by $68 \%$ at foraging sites, and reducing body mass by $10 \%$ (Ydenberg, Butler, Lank, 
Smith, \& Ireland, 2004). Plovers are likely to encounter a high number of raptors and mesopredators while migrating and wintering, although predation numbers or impact have not been quantified for wintering Snowy Plovers in the South San Francisco Bay area. High predation pressure and increased non-lethal predation are expected to reduce the ability of plovers to optimally forage, resulting in high mortality of wintering and migrating flocks and reduced success of breeding flocks in the Bay Area.

Documented predators of plover adults, chicks, or eggs include the California gull (Larus californicus), gray fox (Urocyon cinereoargenteus), red fox (Vulpes vulpes), Northern harrier (Circus cyaneus), red-tailed hawk (Buteo jamaicensis), peregrine falcon (Falco peregrinus), ruddy turnstone (Arenaria interpres), and common raven (Corvus corax) (Demers \& Robinson-Nilsen, 2012). In addition, opportunistic animals such as herons, egrets, raccoons, or skunks that encounter them may take chicks and eggs.

Recent research has illustrated how predation, in combination with other factors, can have a tremendous affect on the stability of the population locally and regionally. Analysis of range wide plover monitoring data has shown a latitudinal gradient in adult survival, with southern populations achieving a greater survival rate than northern populations (Hudgens et al., 2014). This results in source and sink populations within the range, with populations in Northern California up through Washington predicted to become extinct without continued dispersal from Southern populations. While simulation models predicted that the Pacific Coast population was stable overall, an important finding was that the average expected metapopulation was most sensitive to fluctuations in adult survival, with nearly twice the effect compared to chick hatching 
rates or juvenile survival (Hudgens et al., 2014). Thus, it is significant to identify more precisely how predation may affect adult survival within the Bay Area during winter. 


\section{Problem Statement}

Within the San Francisco Bay Area, plovers face a number of threats, including human altered habitats and high levels of predation by numerous mesopredators and raptors. The Project is a large wetland restoration project that will change and potentially largely eliminate Snowy Plover habitat in the region. As the Project returns ponds to tidal wetland, less of the dry, flat, and sparsely vegetated habitat will be available to plovers for foraging and breeding. It is an objective of the Project, however, to meet its own Snowy Plover recovery goal of 250 breeding birds within the Project footprint (South Bay Salt Pond Restoration Project, 2007). In order to prevent the Project from having a negative impact on plovers and, ultimately, not achieving the recovery goals set forth by USFWS and the Project, greater understanding of the specific microhabitat requirements for high quality plover foraging sites is needed. Considering the varying adult survival rates of plover populations throughout the range, and the significance of adult survival in establishing stable reproductive colonies, it is vital to have a greater understanding of wintering plover activity within the San Francisco Bay Area. In particular, the extent to which predation and risk-forage trade-offs in various wintering habitats are affecting Snowy Plover numbers is essential and has not yet been evaluated.

The objective of this thesis research was to identify how winter foraging habitat selection of western Snowy Plovers, particularly during mid-late winter, when all chicks have fledged and wintering flocks have formed, is influenced by selected habitat characteristics, predation, and invertebrate prey abundance (SFBBO 2003-2013; Brindock \& Colwell, 2011). To assess these relationships, data were collected on 
wintering western Snowy Plovers and their foraging habitat within Eden Landing and the Refuge, both located in the San Francisco Bay, and addressed the following research questions and hypotheses.

\section{Research Questions}

1. What habitat characteristics typically characterize wintering plover foraging habitat?

2. What invertebrate species are available to wintering plovers in ponds where the birds are found, and in what relative abundances?

3. What predator species occur at salt ponds, and in what abundance? What habitat characteristics most significantly characterize ponds used by predators?

4. In what ponds are plovers found, and in what numbers?

5. Where are wintering plovers coming from?

\section{Hypotheses}

$\mathrm{H}_{0}$ 1: Moisture and substrate size at plover present sites do not differ from plover absent sites.

$\mathrm{H}_{0}$ 2: Insect densities at plover present sites and plover absent sites do not differ.

$\mathrm{H}_{0} 3$ : Plover behavior and flock size are not correlated with predator presence. 


\section{Methods}

\section{Study System}

This study took place in the South San Francisco Bay at Eden Landing, located on the eastern shore of the San Francisco Bay, approximately $40 \mathrm{~km}$ northwest of San Jose and $52 \mathrm{~km}$ southeast of San Francisco, and two sites at the Refuge. The Ravenswood Complex is located on the western shore of the San Francisco Bay, approximately $30 \mathrm{~km}$ northwest of San Jose and $49 \mathrm{~km}$ southeast of San Francisco, while the Warms Springs Complex is located along the eastern shore of the San Francisco Bay, approximately 21 $\mathrm{km}$ north of San Jose and $65 \mathrm{~km}$ southeast of San Francisco. These sites are all part of the Project (Figure 1).

Annual precipitation ranges widely in the study area, from $77 \mathrm{~cm}$ per year in the wettest areas to $36 \mathrm{~cm}$ per year in the driest, with $90 \%$ of the precipitation occurring from November through April (Watson, 2004). The mean annual temperature is $15.6^{\circ} \mathrm{C}$, with low mean temperature of $9.8^{\circ} \mathrm{C}$ in January and high mean temperature of $20.7^{\circ} \mathrm{C}$ (Watson, 2004). The mean elevation for Eden Landing is approximately $1.5 \mathrm{~m}$ above sea level, with the Refuge at a similar elevation (Athearn, Takekawa, Jaffe, Hattenbach, \& Foxgrover, 2010).

The greater San Francisco Bay Area has a human population of 7.15 million people (Bay Area Census, 2010), distributed in pockets of dense urbanization, as well as areas of suburbanization characterized by sprawling development. Prior to human settlement, the San Francisco Bay encompassed nearly 220,000 ha of tidal marsh and 80,000 ha of salt marsh, making it the largest estuary on the Pacific Coast and a critical 
habitat for wildlife (Williams \& Faber, 2001). Development of coastline and alteration of water flow were accomplished through diking and filling of more than $90 \%$ of original marshland, prompting the passage of wetland protection legislation in 1966 (Williams \& Faber, 2001). From 1972 on, multiple restoration efforts by various organizations have focused on restoring the Bay's tidal and salt marshes (Williams \& Faber, 2001). Eden Landing is a core part of the Project, comprising approximately 5,500 acres of former salt ponds (Demers \& Robinson-Nilsen, 2012). CDFW and volunteers working with the Save the Bay Foundation have restored 630 acres of former salt ponds by removing invasive plants and opening ponds E8A, E9, and E8X to tidal action (South Bay Salt Pond Restoration Project, 2013).

Recent studies show that the restoration has had a positive effect on wildlife, as a greater abundance of most shorebirds and ducks were seen in the restored ponds as compared to the commercially operated salt ponds (Athearn et al., 2012). The site is a critical habitat for numerous threatened and endangered species, including the federally listed western Snowy Plover, California ridgeways rail, Rallus longirostris obsoletus, salt marsh harvest mouse, Reithrodontomys raviventris (USFWS Species Reports, 2013), and the state listed black rail, Laterallus jamaicensis (CDFW, 2013).

Eden Landing is important breeding habitat for plovers, as recent surveys show that it contained approximately 174 nests during the 2015 season, nearly $60 \%$ of the total number of nests detected in the Bay Area in 2015 (SFBBO, 2015). The Ravenswood complex is another critical component of the restoration project. RSF2, one of the ponds 
within the complex, was the first pond restored and opened to tidal action as part of the project.

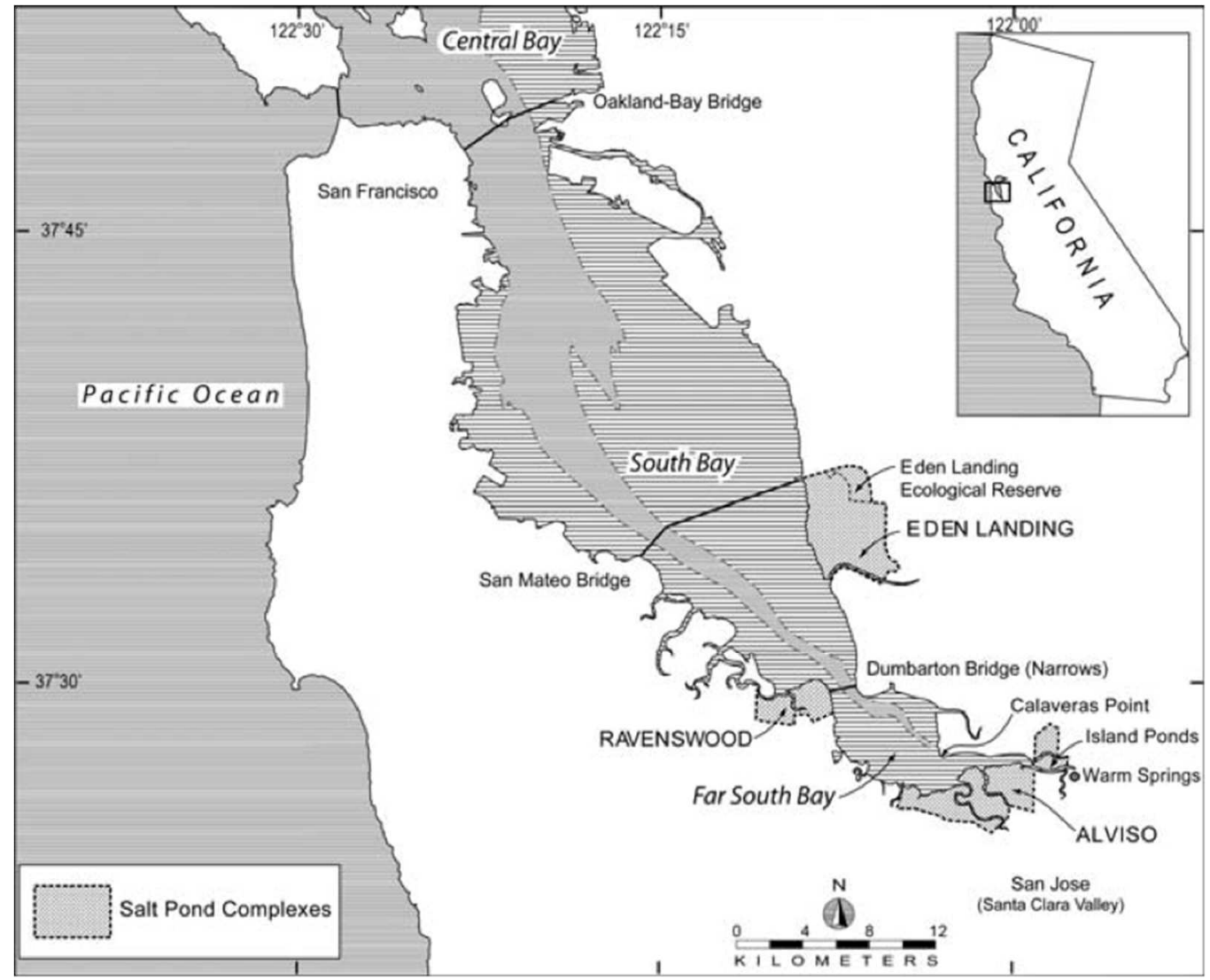

Figure 1. South Bay salt pond map and location of Eden Landing, Ravenswood, and Warm Springs. Reprinted from Brew \& Williams, 2010

\section{Study Design}

This study employed observational and direct measurements in order to assess Snowy Plover foraging habitat characteristics and prey preferences. Fieldwork for season 1 spanned from December 2013 to March 2014 and December 2014 to March 2015 for season 2. Ponds were visited two to three times per week depending upon weather conditions. 


\section{Data Collection}

Reconnaissance. During December of 2013 and December 2014, I surveyed all suitable ponds at Eden Landing and the Refuge systematically to determine the location of available habitat both used and not used by plovers. All ponds were scan sampled for plovers and predators. Throughout the study sites, surveys focused on all pond habitat dry enough to be considered potential plover habitat. Due to variability in precipitation, pond management, and SBSPRP activities, available habitat varied dramatically between the seasons, a very common occurrence. This early surveying helped to direct research efforts in the beginning of data collection for both seasons.

During this study, plovers were observed at a total of 13 ponds throughout the South San Francisco Bay. These included ponds E6A, E6B, E8, E12, E13, E14, E15B, and E16B, located at Eden Landing and ponds A22, A23, RSF2, and R3, located at the Refuge. Ponds A23 and R3 were not visited during season 2 due to changes in pond management, resulting in a lack of available habitat due to flooding.

Bird observations. Approximately three times per week from January through March in 2014 and 2015, my research assistant and I visited ponds at Eden Landing and the Refuge, focusing on ponds where birds had been seen during the reconnaissance phase. When plovers were found, the locations of the birds were recorded on a map. Before recording the initial behavior of plovers, five minutes was allowed to elapse prior to beginning observation to allow for acclimation of birds. At sites with birds, initial behavior was recorded (roosting or foraging) using a Kowa Prominar TSN-66 observation scope with 60x magnification, and Alpen $8 \times 42$ wide angle binoculars to 
accurately observe plovers. The flock was then observed for 30 minutes to collect data on bird behavior, use of habitat and other shorebirds present. Data were collected at 5minute intervals during the 30 minutes of observation. For each sighting, the species of shorebirds within approximately $25 \mathrm{~m}$ were recorded. Predator presence and behavior were documented at each observation point. All predators within approximately $100 \mathrm{~m}$ radius of the edge of the pond were included.

Microhabitat sampling. Within 48 hours after each bird observation, microhabitat characteristics were recorded at the location of the plover sightings. At these sites, data were collected in 7 m-radius circles centered on the observation location. Four circles $7 \mathrm{~m}$ apart in each area used by plovers were plotted and sub-sampled. Within the circles, total plant cover for the entire area was assessed by visual estimate as a percentage of the plot, and plant height was obtained by averaging five random measurements from within the circle using a ruler to the nearest $\mathrm{mm}$. Substrate was collected using a trowel and plastic bags, and was taken to the Environmental Studies laboratory at San Jose State University. There, the type and size of soil particles were identified. Soil moisture was measured in the field at four equidistant locations along the circumference of the circle and one in the center using a Vegetronix VG-Meter-200 handheld moisture meter. Distance to levee, borrow ditch, water, and perch were measured using a Bushnell Elite $15001 \mathrm{~m}$ accuracy laser rangefinder in Season 1 and a Bushnell Sport 850 4x20 mm laser rangefinder in Season 2. Water depth was measured using a field grade ruler and percent water cover was visually estimated within each 
sampling circle. GPS coordinates were recorded for all site sampling plots using a Garmen eTrex Venture handheld personal gps.

Data in sampling plots were collected at plover absent sites, potentially suitable ponds or large parts of ponds where no plover presence had been observed during that winter season. These sites were determined via the reconnaissance portion of research, allowing identification of ponds and sections of ponds that appeared to provide the necessary habitat features for plovers, yet did not support any plover foraging activity. The sampling plot location was determined by generating random distances and directions on pond bottom using the Excel function RANDBETWEEN in Season 1, and Random.org in Season 2. This generated an initial number of paces to walk, a direction to turn once the number of paces was reached, and a number of paces to walk in that direction to reach the sampling location. Sampling methods in each plot were identical to those used in plover present sites.

During both Seasons 1 and 2, a total of 15 plover present and 15 plover absent samples were collected, combining for a total of 30 of each sample type over the course of the study.

Invertebrate sampling. During season 1, invertebrates were visually observed to determine relative abundance. This was achieved by slowly walking a transect across the center of the circle, counting all insects seen. During season 2, invertebrates were collected to determine species abundance, prey availability, and community composition. Sticky traps were set up based upon methods used by Anteau and Sherfy (2010) in their study of piping plover foraging. At each circle, a $2.5 \mathrm{ft}$ x $2.5 \mathrm{ft}$ exclosure was randomly 
placed to conduct sampling within and prevent entangling vertebrates. Within the enclosure, two paint sticks were placed vertically and horizontally into the ground. Both sticks were covered with Tanglefoot insect trap coating, with the vertical stick placed $10 \mathrm{~cm}$ from the horizontal stick. Traps were collected after three hours, wrapped in plastic wrap, and refrigerated in Tupperware until analyzed. All specimens were measured lengthwise and when possible, identified to family under an AmScope WF10X magnification dissecting microscope.

\section{Data Analysis}

To analyze whether plovers were choosing to forage in areas of high insect density, a t-test comparing plover absent and plover present sites was used. t-tests were also utilized to compare significant difference between soil moisture and soil particle size at plover absent versus plover present sites. Pearson's product-moment correlations were used to test the relationship between potential predator number and plover flock size and activity, using these parameters: average number of predators per pond, average number of raptors per pond, maximum number of plovers foraging per observation, minimum number of plovers foraging per observation, average number of plovers per observation, percent of plovers foraging per observation, and percent of plovers roosting per observation.

To characterize winter plover foraging habitat characteristics, a principle component analysis (PCA) was used. Prior to running PCAs, highly correlated variables were identified, and all but one of the correlated variables was eliminated from the 
model. Only PCA loadings with an absolute value greater than or equal to 0.300 were considered significant, and thus reported in the analysis. 


\section{Results}

\section{Plover Locations In Ponds}

Throughout both seasons, the highest abundance of plovers was observed at pond A23 (Table 1). Plovers were most consistently observed at Pond E14 (Table 1).

Table 1. Average number of plovers observed per pond

\begin{tabular}{|c|c|c|c|c|c|c|c|c|c|c|}
\hline Pond & $\mathbf{A 2 2}$ & $\mathbf{A 2 3}$ & $\mathbf{E 6 B}$ & $\mathbf{E 8}$ & $\mathbf{E 1 2}$ & $\mathbf{E 1 3}$ & $\mathbf{E 1 4}$ & $\mathbf{E 1 6 B}$ & $\mathbf{R 3}$ & RSF2 \\
\hline $\begin{array}{c}\text { Average } \\
\text { observed }\end{array}$ & 23.10 & 80.50 & 4.54 & 3.93 & 3.00 & 25.91 & 21.75 & 21.69 & 3.43 & 8 \\
\hline $\begin{array}{l}\text { \# Surveys } \\
\text { per pond }\end{array}$ & 3 & 2 & 4 & 2 & 1 & 8 & 20 & 6 & 1 & 1 \\
\hline
\end{tabular}

Ponds E12, E13, and E14 comprise the Whale's Tail Loop at Eden Landing, which was visited most frequently over the course of both seasons (Figure 2).

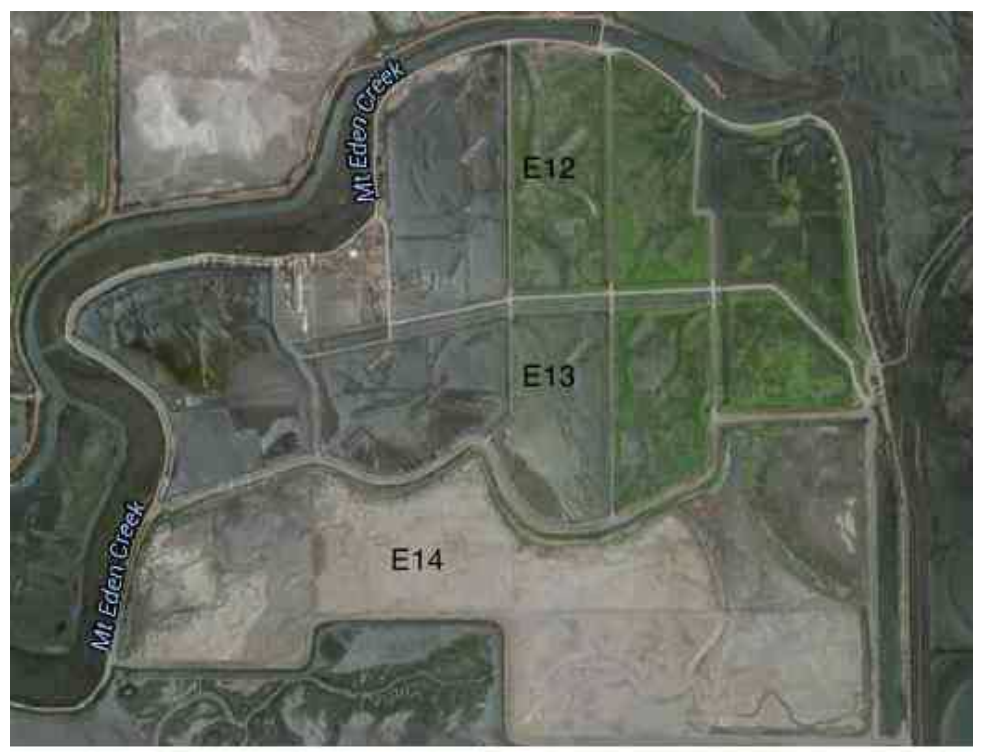

Figure 2. E14 was managed specifically for plovers in Season 2. Retrieved from https://www.google.com/maps/@37.6119081,-122.1250825,2375m

Ponds E8, E6A, and E6B, which comprise the Old Alameda Creek loop, were visited infrequently over both seasons due to the overall lack of available habitat (Figure 3). 


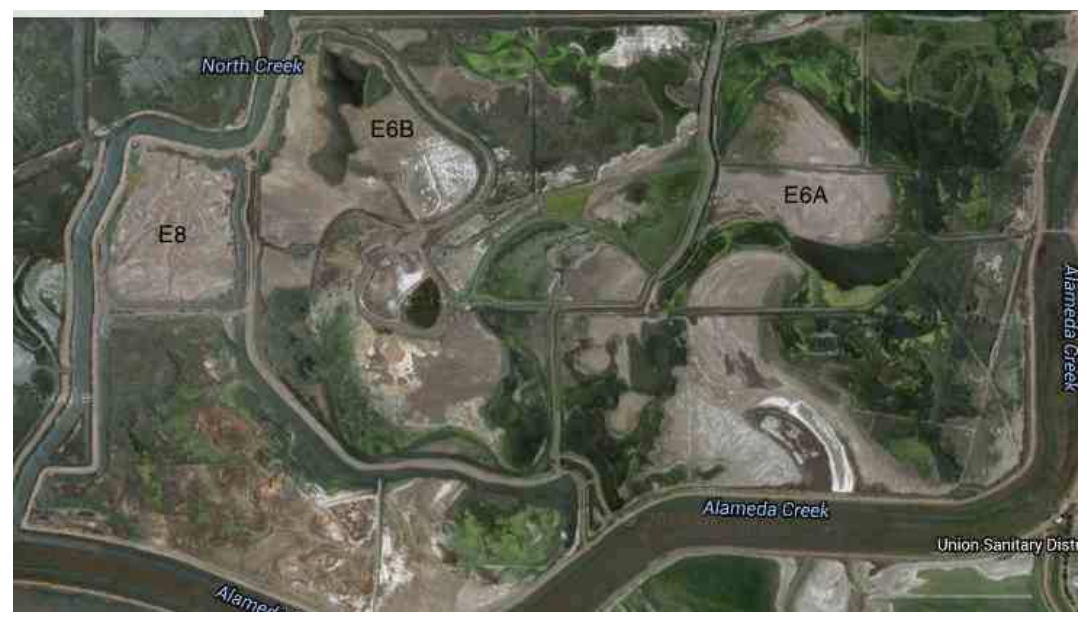

Figure 3. Ponds E8, E6A, E6B largely flooded during both seasons. Retrieved from https://www.google.com/maps/@37.5987004,-122.1073777,2222m

Ponds E14B-16B and E11 comprise the Mt. Eden Creek loop. Pond E16B was the only pond with plover sightings over the course of both seasons, with all coming during the first season (Figure 4).

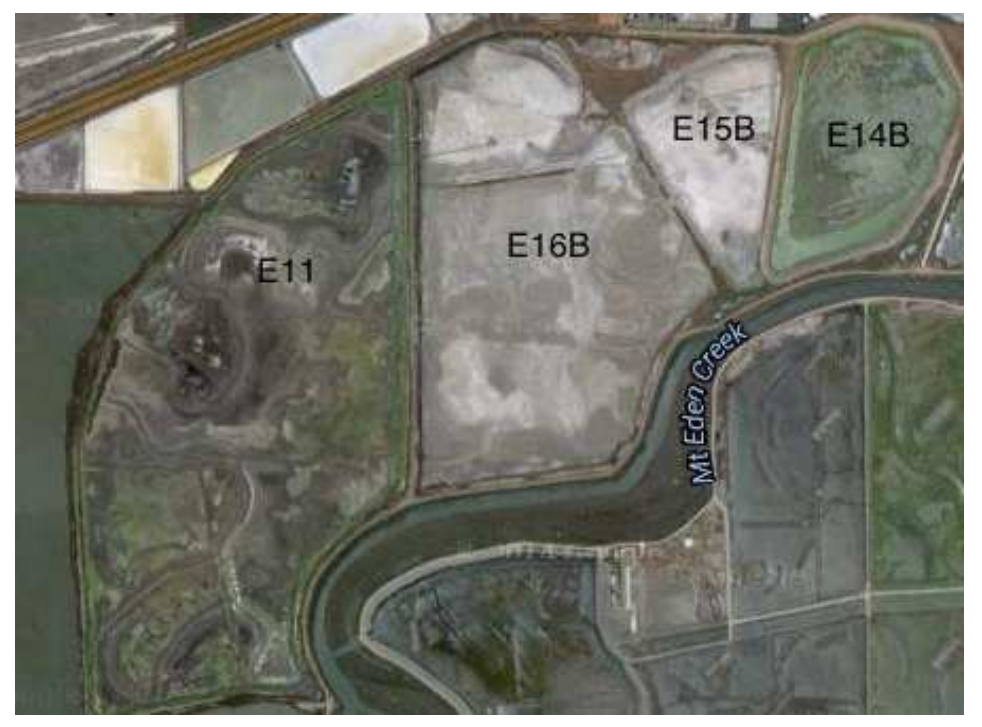

Figure 4. E16B hosted large plover flocks in Season 1, but there were no sightings in Season 2. Retrieved from https://www.google.com/maps/@37.6152132,122.1334258,2813m 
Ponds R1-5 and RSF2 comprise the Ravenswood Complex. Pond RSF2 was visited most often due to dedicated plover habitat, while ponds R1-5 were flooded and largely unavailable (Figure 5).

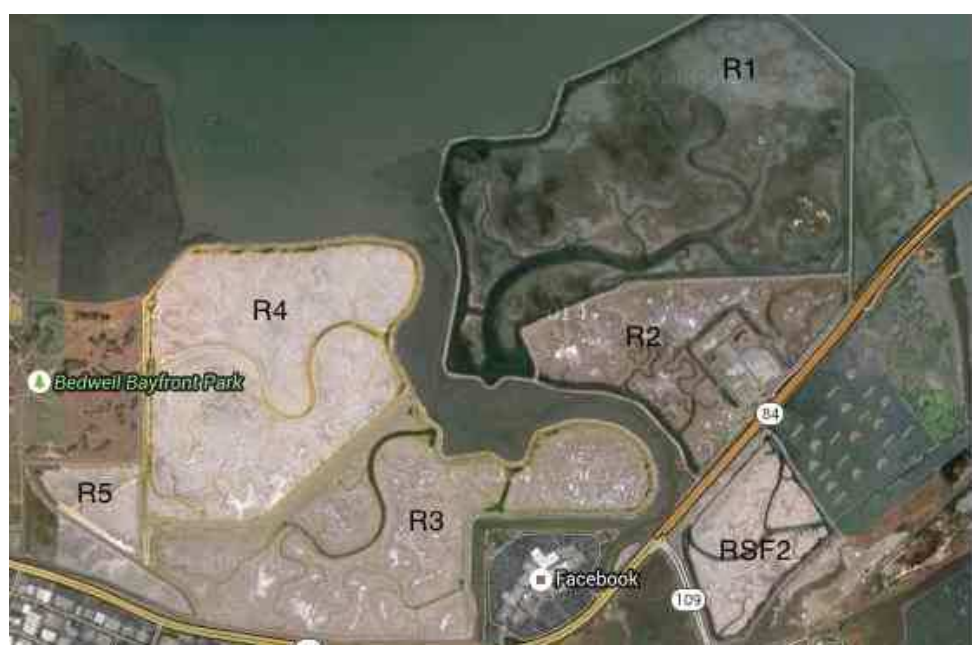

Figure 5. Ponds R1-5. Retrieved from https://www.google.com/maps/@37.4952173,122.1526467,3273m

Ponds A22 and A23, which comprise the Warm Springs ponds, were visited infrequently over the course of both seasons. Pond A23 was flooded during season 2 and was therefore unavailable (Figure 6).

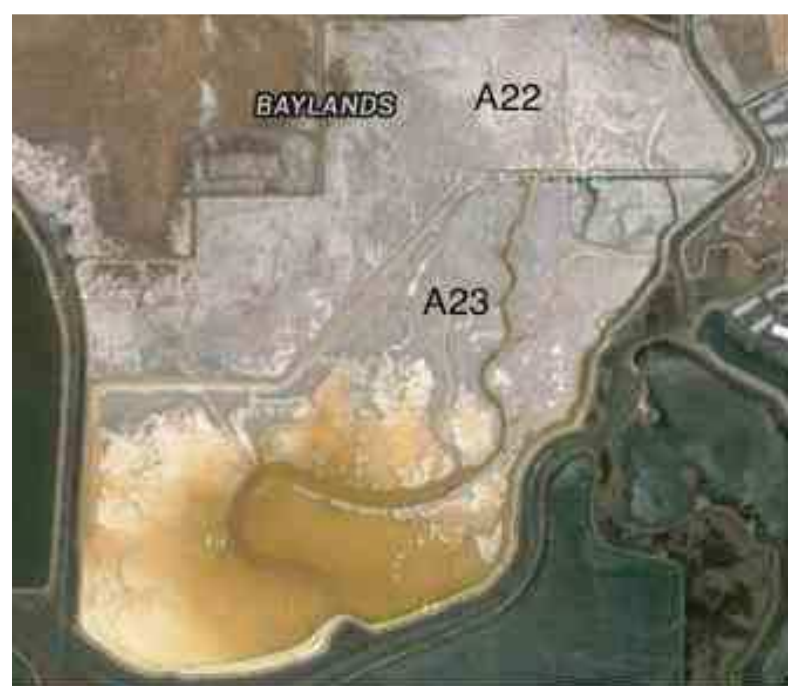

Figure 6. Ponds A22 and A23. Retrieved from https://www.google.com/maps/@37.4788052,-121.9644018,2811m 
Plover behavior was similar during both seasons. Flock size was statistically similar, while plovers spent the majority of their time foraging (Table 2).

Table 2. Plover numbers and behavior by season

\begin{tabular}{|l|l|l|}
\hline Plover Behavior & Season 1 & Season 2 \\
\hline Average plovers per flock & $22.81 \pm 30.00$ & $23.04 \pm 15.01$ \\
\hline Average max. per flock & $26.25 \pm 30.72$ & $20.59 \pm 16.86$ \\
\hline Average min. per flock & $19 \pm 27.86$ & $9.79 \pm 12.23$ \\
\hline Total birds observed & 525 & 597 \\
\hline Average\% time foraging & 57.10 & 72.60 \\
\hline Average \% time roosting & 42.90 & 27.40 \\
\hline
\end{tabular}

\section{Migration Origin}

RU3 banded birds. Of 597 plovers observations, I detected 25 unique full band combinations that could potentially identify banding origins. Of these individual units, 12 were identified as plovers banded by SFBBO in the Restoration Project area. Seven were males, with four banded as adults and one banded as a chick during the 2014 breeding season at E14, one banded during the 2010 breeding season at E12, and one banded during the 2008 breeding season as a chick at E8A. Two were females, including one individual banded as an adult and another as a chick during the 2014 breeding season at E14. Three individuals were of unidentified sex, with an individual banded during the 2014 breeding season at E8 and RSF2, respectively, and one banded during the 2013 breeding season at E12.

Migrant banded birds. Ten combinations were recorded from outside Recovery Unit 3. Two individuals were 2014 breeding season juveniles from the Monterey Bay area. Point Blue banded one individual at Pajaro Spit, and another was hatched at Ocean Dunes State Vehicular Recreation Area, but brought to Monterey Bay Aquarium, where it 
was raised and fledged until release at Moss Landing State Beach. Three individuals were migrants from Oregon. Two individuals were 2014 breeding season juveniles, with one coming from Overlook Beach in Douglas County, and another coming from Bandon Beach in Coos County; the third Oregon bird hatched in 2013 at New River Habitat Restoration Area in Coos County. Four individuals, while there is some uncertainty, appear to have been banded in Utah at the Great Salt Lake.

\section{Foraging Habitat Characteristics}

Soil moisture, water depth, and ditch distance were highly correlated with other variables, and all were removed from both PCAs to prevent over-accounting for factors. For plover present samples, soil moisture was significantly correlated with water cover $(\mathrm{r}=0.632$,p-value $<0.001)$; water depth was significantly correlated with water cover $(\mathrm{r}=0.810, \mathrm{p}$-value $<0.001)$; and ditch distance was significantly correlated with levee distance $(\mathrm{r}=0.833$, $\mathrm{p}$-value $<0.001)$. For plover absent samples, soil moisture was significantly correlated with perch distance $(r=0.375, \mathrm{p}$-value $=0.041)$; water depth was significantly correlated with water cover $(\mathrm{r}=0.608$, $\mathrm{p}$-value $<0.001)$; and ditch distance was significantly correlated with water cover $(\mathrm{r}=0.502, \mathrm{p}$-value $=0.005)$, levee distance $(\mathrm{r}=0.789, \mathrm{p}$-value $<0.001)$, and perch distance $(\mathrm{r}=0.465, \mathrm{p}$-value $=0.010)$. For plots where

plovers were observed, the PCA produced three components that explained $70.7 \%$ of the overall variance in the data. Components 1 and 2 explained $29.95 \%$ and $21.67 \%$ of the variance in the data, respectively. Component 1 showed that increasing plant height and water cover were significant predictors of plover habitat, while increasing levee distance, plant cover and decreasing water distance were moderate predictors of plover habitat. 
Component 2 showed that increasing perch distance and levee distance were significant predictors of plover habitat, while decreasing water distance and plant cover were moderate predictors of plover habitat (Table 3; Figure 7).

Table 3. Plover Present PCA loadings

\begin{tabular}{|l|l|l|l|}
\hline Variable & Component 1 & Component 2 & Component 3 \\
\hline Plant Height & .725 & -.275 & .310 \\
\hline Water Cover & .820 & .008 & -.313 \\
\hline Levee Distance & .460 & .651 & .260 \\
\hline Perch Distance & -.256 & .744 & .420 \\
\hline Water Distance & -.470 & -.387 & .441 \\
\hline Plant Cover & .316 & -.312 & .718 \\
\hline
\end{tabular}

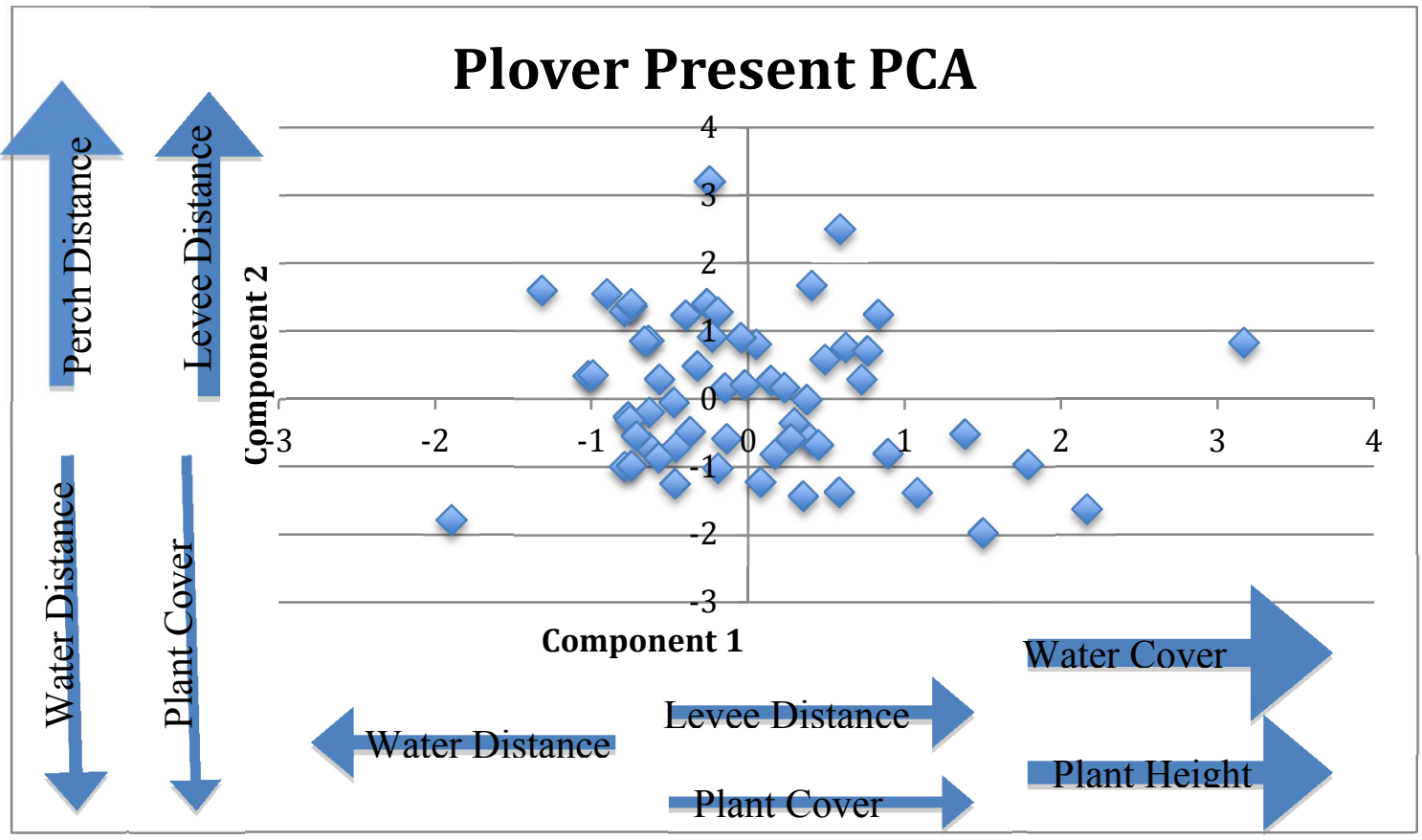

Figure 7. Plover Present Factor Scores

For plot samples in which plovers were not observed, the PCA produced three components that explained $73.5 \%$ of the overall variance in the data. Components 1 and 2 explained $33.15 \%$ and $21.90 \%$ of the variance, respectively. Component 1 showed that increasing levee distance, perch distance and water cover and decreasing plant height 
were significant predictors for these sites, while decreasing water distance was a moderate predictor for the plover absent sites. Component 2 showed that increasing plant cover and plant height were significant predictors for plover absent sites, while decreasing perch distance and water distance were moderate predictors (Table 4; Figure 8).

Table 4. Plover Absent PCA Loadings

\begin{tabular}{|l|l|l|l|}
\hline Variable & Component 1 & Component 2 & Component 3 \\
\hline Plant Height & -.579 & .543 & .253 \\
\hline Water Cover & .586 & .158 & -.512 \\
\hline Levee Distance & .763 & .127 & .414 \\
\hline Perch Distance & .665 & -.455 & .398 \\
\hline Water Distance & -.484 & -.461 & .509 \\
\hline Plant Cover & .273 & .747 & .411 \\
\hline
\end{tabular}

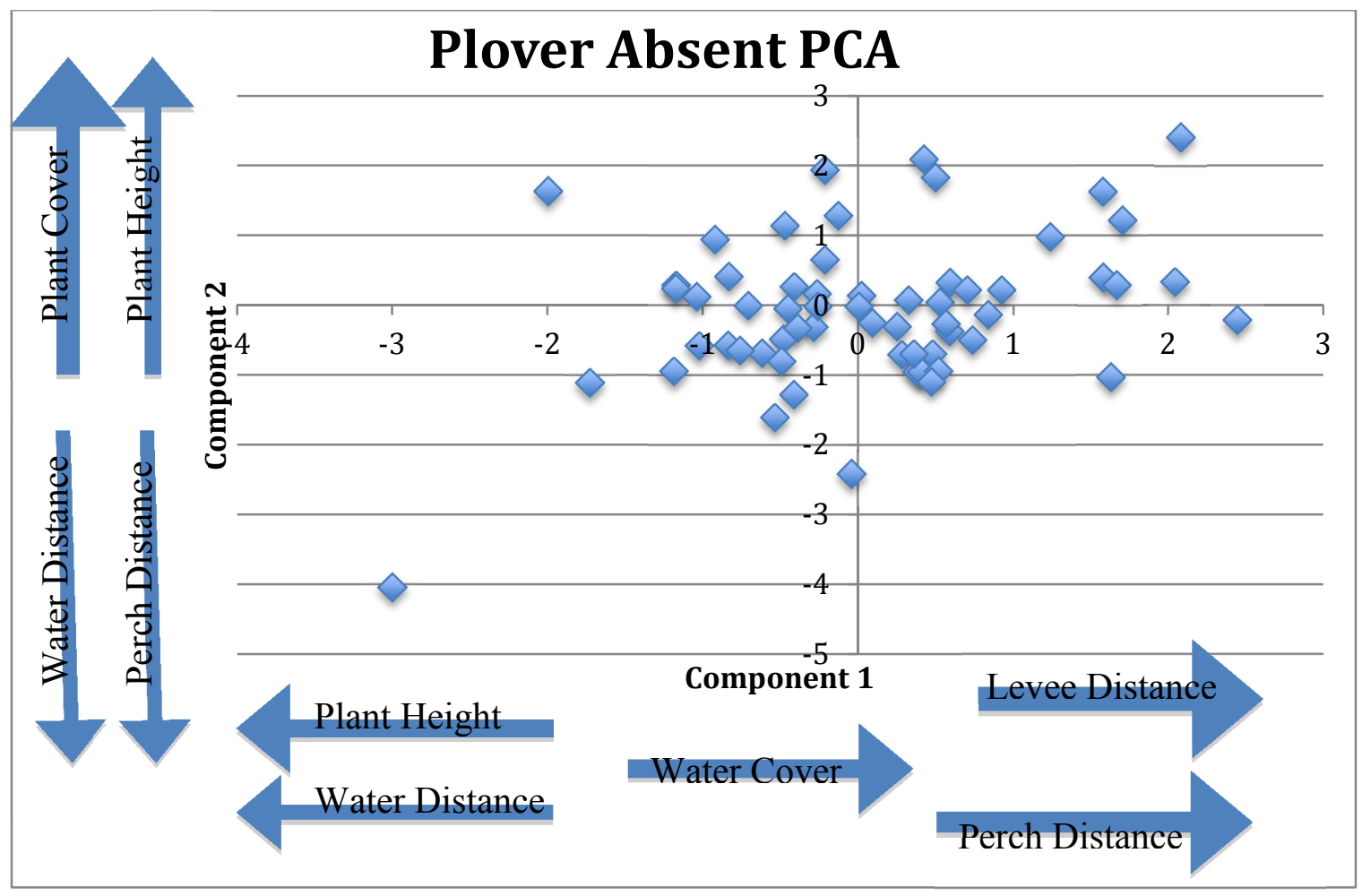

Figure 8. Plover Absent Factor Scores 
Comparing plover foraging and plover absent loadings showed that there were different trends between the two sampling site types (Table 5).

Table 5. Comparison of PCA Loadings

\begin{tabular}{|l|l|l|l|l|}
\hline Variable & $\begin{array}{l}\text { Plover } \\
\text { Present } \\
\text { Component 1 }\end{array}$ & $\begin{array}{l}\text { Plover } \\
\text { Absent } \\
\text { Component 1 }\end{array}$ & $\begin{array}{l}\text { Plover } \\
\text { Present } \\
\text { Component 2 }\end{array}$ & $\begin{array}{l}\text { Plover } \\
\text { Absent } \\
\text { Component 2 }\end{array}$ \\
\hline Plant Height & .725 & -.579 & -.275 & .543 \\
\hline Water Cover & .820 & .586 & .008 & .158 \\
\hline Levee Distance & .460 & .763 & .651 & .127 \\
\hline Perch Distance & -.256 & .665 & .744 & -.455 \\
\hline Water Distance & -.470 & -.484 & -.387 & -.461 \\
\hline Plant Cover & .316 & .273 & -.312 & .747 \\
\hline
\end{tabular}

Ho1. The soil moisture at sites used by plovers was significantly greater $(12.20 \pm 2.90)$ than at plover absent sites $(9.52 \pm 2.27)(\mathrm{t}=-3.979, \mathrm{df}=58, \mathrm{p} \leq 0.01)$. The soil particle size did not differ between plover absent $(X=4.87 \pm 2.37)$ and plover present samples $(\mathrm{X}=5.67 \pm 2.06))(\mathrm{t}=-1.395, \mathrm{df}=58, \mathrm{p}$-value $=0.168)$.

\section{Invertebrate Availability}

During 15 plover present foraging microhabitat sampling surveys, a total of 216 invertebrates were trapped, while 217 invertebrates were trapped during 15 plover absent surveys. Of the combined 433 invertebrates collected, 400 were identified as brine flies, Ephydra millbrae, five were identified as members of the Mosquito family, Culicidae, and the remaining 28 invertebrates were classified as unidentified Diptera species.

Ho2. Invertebrate density was significantly greater at sites used by plover $(X=5.90 \pm 4.05)$ than at plover absent sites $(X=2.63 \pm 3.02)(t-v a l u e=2.502, \mathrm{df}=28, \mathrm{p}$ value $=0.018$ ) in season 1 . For season 2 , the difference was not significant (t-value=$0.889, \mathrm{df}=28, \mathrm{p}$-value $=0.381)($ plover present $: \mathrm{X}=10.1 \pm 12.5$; plover absent: $X=18.73 \pm 35.32$ ). During season 2, invertebrate average length at plover present 
$(\mathrm{x}=2.56 \pm 0.75)$ sites was significantly greater than at plover absent $(\mathrm{x}=2.10 \pm 0.80)(\mathrm{t}-$ value $=6.181, \mathrm{df}=431, \mathrm{p} \leq 0.01)$.

\section{Predator Abundance}

During 20 predator observational surveys in season 1, a total of 629 potential predators were seen. California gulls comprised over 90\% (571) of these total sightings, with 550 observed at A23 alone (Table 6). Red tailed hawks (19), Northern harriers (12), peregrine falcons (8), American crows (5), and common ravens (4) were the only other species seen in appreciable numbers (Table 6).

Table 6. Total predator sightings by species and pond during Season 1

\begin{tabular}{|c|c|c|c|c|c|c|c|c|c|c|c|c|c|c|}
\hline$\underline{\text { Raptors }}$ & तี & $\stackrel{2}{2}$ & 데 & $\frac{m}{m}$ & $\stackrel{\nabla}{ \pm}$ & 孚 & 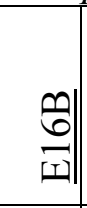 & $\begin{array}{l}\infty \\
\text { c工川 }\end{array}$ & $\begin{array}{l}\mathbb{6} \\
\text { 페 }\end{array}$ & $\begin{array}{c}0 \\
0 \\
0\end{array}$ & $\approx 1$ & $\begin{array}{l}\sqrt{1} \\
\underline{2} \\
\approx\end{array}$ & $\stackrel{\frac{\pi}{0}}{0}$ & 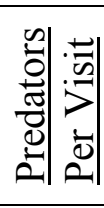 \\
\hline NOHA & & 2 & 1 & & 3 & & & 3 & & 3 & & & 12 & 0.14 \\
\hline RTHA & 2 & 4 & & & & & 3 & & 8 & 1 & & & 19 & 0.24 \\
\hline PEFA & 2 & & & & 4 & & & & 1 & & & 1 & 8 & 0.15 \\
\hline AMKE & & & & & & 1 & & & & & & & 1 & 0.02 \\
\hline WTKI & & & & & & 2 & & & & & & & 2 & 0.04 \\
\hline MERL & & & & & & & & & & & 2 & & 2 & 0.07 \\
\hline \multicolumn{15}{|l|}{ Corvids } \\
\hline$\overline{\mathrm{AMCR}}$ & 5 & & & & & & & & & & & & 5 & 0.06 \\
\hline CORA & 2 & 2 & & & & & & & & & & & 4 & 0.05 \\
\hline \multicolumn{15}{|l|}{ Gulls } \\
\hline$\overline{\mathrm{CAGU}}$ & & 550 & & & 10 & & 11 & & & & & & 571 & 6.85 \\
\hline GULL & & & 2 & & & & & & & & & & 2 & 0.02 \\
\hline \multicolumn{15}{|l|}{ Shorebirds } \\
\hline SNEG & & & & & 1 & & & & & & & & 1 & 0.01 \\
\hline GREG & & & & 1 & & & & & & & & & 1 & 0.01 \\
\hline GBHE & & & & 1 & & & & & & & & & 1 & 0.01 \\
\hline Pond Total & 11 & 558 & 3 & 2 & 18 & 3 & 14 & 3 & 9 & 4 & 2 & 1 & 629 & \\
\hline
\end{tabular}

During 30 predator observational surveys in season 2, a total of 2,878 potential

predators were seen. Gull species, including California gulls (283), Western gulls (402), 
Herring gulls (3), ring-billed gulls (4), and unidentified gulls (1968), comprised over 92 $\%$ of all sightings. Red tailed hawks (28), Northern harriers (23), great egret (17) American crow (16), peregrine falcon (12), and common raven (12) were the next most frequently sighted species (Table 7).

Table 7. Total predator sightings by species and pond during Season 2

\begin{tabular}{|c|c|c|c|c|c|c|c|c|c|c|c|c|c|}
\hline$\underline{\text { Raptors }}$ & तै & 2 & 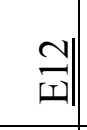 & $\frac{m}{[-1}$ & 叫 & $\underset{\text { 竎 }}{|c|}$ & $\begin{array}{l}\text { 예 } \\
\text { 데| }\end{array}$ & $\begin{array}{l}\infty \\
\text { 페 }\end{array}$ & $\begin{array}{l}\mathbb{\mho} \\
\text { II }\end{array}$ & $\begin{array}{l}\text { श्री } \\
\text { In }\end{array}$ & 됭 & 氶 & 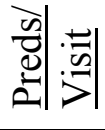 \\
\hline NOHA & 2 & & 2 & 1 & 11 & 1 & 1 & 2 & & 3 & & 23 & 0.23 \\
\hline RTHA & 2 & 2 & 2 & 1 & 3 & & 1 & 6 & 7 & 3 & & 28 & 0.37 \\
\hline PEFA & & & & & 11 & 1 & & & & & & 12 & 0.08 \\
\hline AMKE & 1 & & & & & & & & & & & 1 & 0.02 \\
\hline WTKI & & & & & & 1 & & & & & & 1 & 0.02 \\
\hline MERL & & & & & & & & & 1 & & & 1 & 0.01 \\
\hline BAEG & 1 & & & & & & & & & & & 1 & 0.02 \\
\hline \multicolumn{14}{|l|}{ Corvids } \\
\hline$\overline{\mathrm{AMCR}}$ & 16 & & & & & & & & & & & 16 & 0.29 \\
\hline CORA & 10 & & & & & & & & & & 2 & 12 & 0.32 \\
\hline \multicolumn{14}{|l|}{$\underline{\text { Gulls }}$} \\
\hline$\overline{\mathrm{CAGU}}$ & 225 & & 12 & & & & 42 & 3 & & & 1 & 283 & 5.19 \\
\hline WEGU & 400 & & 1 & & & & & 1 & & & & 402 & 7.16 \\
\hline RBGU & & & & & & & 2 & & & & 2 & 4 & 0.19 \\
\hline HERG & & & & & 2 & & & & & 1 & & 3 & 0.02 \\
\hline GULL & 1714 & 250 & & & & & 1 & & & & 3 & 1968 & 35.3 \\
\hline \multicolumn{14}{|c|}{ Shorebirds } \\
\hline SNEG & & & & & 5 & & 1 & 4 & & & & 10 & 0.11 \\
\hline GREG & & & 1 & & 9 & & 2 & 3 & 1 & & 1 & 17 & 0.23 \\
\hline GBHE & & & & & 4 & & & 1 & 1 & 3 & & 9 & 0.09 \\
\hline \multicolumn{14}{|l|}{ Other } \\
\hline$\overline{\text { House Cat }}$ & & & & & & & & & 2 & & & 2 & 0.05 \\
\hline $\begin{array}{l}\text { Pond } \\
\text { Total }\end{array}$ & 2371 & 252 & 18 & 2 & 45 & 3 & 50 & 20 & 12 & 10 & 9 & 2878 & N/A \\
\hline
\end{tabular}

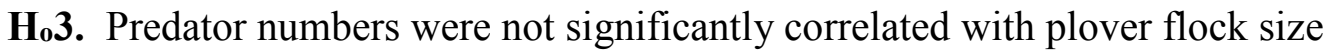
maximum $($ Correlation $=0.027, \mathrm{p}$-value $=0.853)$ or minimum $($ Correlation $=0.070, \mathrm{p}$ - 
value $=0.636$ ). Predator numbers were not significantly correlated with plover behavior, including \%Foraging/Roosting (Correlation $=-.142$, $\mathrm{p}$-value $=0.336$ ). 


\section{Discussion}

\section{Associated Habitat Characteristics}

One of the main objectives of this project was to identify habitat characteristics in South Bay salt ponds with which wintering plovers were associated. My findings that plovers were associated with areas that had increasing plant height is contrary to findings from Brindock \& Colwell (2011), who studied wintering Snowy Plover along ocean fronting beaches in northern California, as well as general descriptions of plover habitat (Page et al., 1995). This previous research indicated plovers selected for areas that were less vegetated, allowing for increased predator visibility. The discrepancy between past research and this study may be due, at least in part, to major differences in salt pond and beach habitats. Pacific beaches, especially dunes, are prone to rampant invasion by European beach grasses (Barbour et al, 1976), which can reach a height of one meter tall. When these grasses form stands tall and dense enough, they prevent plovers from using the area due to the limited visibility. On the other hand, salt ponds rarely contain dense stands of vegetation due to a combination of frequent seasonal flooding and limited plant species tolerance of high salt and anaerobic soil conditions. The average height of vegetation in ponds sampled during this study was only $43.0 \pm 40.7 \mathrm{~mm}$. Thus, vegetation in salt ponds where plovers were observed would not likely hinder the ability of plovers to detect predators. Why plovers were positively associated with increasing plant height was not tested, although some preliminary research in the North San Francisco Bay found an association between pickleweed and amphipods (Obrebsky \& Irwin, 2001). 
Instead of selecting for sites based upon lack of vegetation, plovers selected for sites based upon increasing distance from levees $(\mu=118 \pm 82 \mathrm{~m})$ and perches $(\mu=120 \pm 80$

$\mathrm{m}$ ), as has been found in past research of plovers in the breeding season at Eden Landing (Robinson, 2008). Levees, similar to invasive dune vegetation, can severely restrict the visibility of plovers and thus reduce the birds' ability to detect predators. Perches pose a direct threat, as they allow predators a hunting and attack advantage. Selecting areas to roost and forage that allow for maximum visibility and distance from predators enables plovers to minimize predation risk and maximize time spent foraging.

\section{Invertebrate Availability}

Within areas that plovers selected for wintering habitat, the results of this study suggest that Snowy Plovers had a relatively small assortment of prey species available for forage on at or above ground level. Species found on site included brine flies, Ephydra millbrae, culicid mosquitoes, and other flies. Brine flies constituted the majority of the invertebrates trapped, and overall were found in relatively even abundances throughout all areas sampled. The species trapped during this study are among a suite of previously documented prey species for plovers in South Bay salt ponds during the breeding season. Documented prey species include the Western tanarthrus beetle, Tanarthrus occidentalis, inchworm moth, Perizoma custodiata, and three species of brine flies, including Ephydra millbrae, E. cinerea, and Lipochaeta slossonoae (Goals Project, 2000). In addition, potential prey species include tiger beetles, Cicindela senilis senilis, summer salt marsh mosquitoes, Aedes dorsalis, Bembidion species ground beetles, and lepidopteran caterpillars (Goals Project, 2000). Most of these species are in larval form during the 
winter, and may have been present in the soil in the areas in which sticky traps were deployed. Thus, it is likely that the diversity and abundance of invertebrates was wider than suggested by the findings of this study.

In a similar system of salt ponds and adjacent bay habitat, Spanish researchers had very different findings for the closely related Kentish plover, Charadrius alexandrinus alexandrinus. They found that plovers utilized mudflats for foraging the majority of time during the winter, mainly foraging upon ragworm, Nereis diversicolor, with aquatic beetles of the genus Octhebius supplementing their diet (Castro et al., 2009). Plovers in the South Bay are known to forage in exposed mudflats at low tide, but there is no information to suggest that they spend such a significant amount of time foraging in mudflats during the winter. While ragworms are present in the San Francisco Bay (Casazza et al., 2014), they have not been documented as a prey item for plovers in the South Bay.

\section{Winter Behavior}

Another significant component of this research concerned wintering plover foraging and roosting time allocation. Over the course of two winter seasons, plovers spent a majority of their time foraging - on average of $64.9 \%$ of their time - and nearly all the rest of their time roosting (35.2\%). This is in contrast to the findings of Castro et al. (2009), who found that wintering female Kentish plovers spent an average of $42.70 \pm .02 \%$ of the day foraging, while males spent an average of $43.60 \pm .01 \%$ of the day foraging. The differences in time spent foraging may have been due to the difference in size and energetic value between flies and ragworms. The average size of invertebrates 
trapped during my study was $2.33 \pm 0.81 \mathrm{~mm}$, while ragworms and other polychaetes can reach lengths of 10-12 $\mathrm{cm}$ (Scaps, 2002). The vast difference in size of these invertebrates translates to very different caloric payoffs per individual, and may indicate that plovers in the South Bay must spend a greater amount of time foraging in order to obtain the same amount of nutrition.

Over the course of two winter seasons of data collection, plovers were observed forming flocks with an average size of 23 birds. Flocking behavior has been shown to reduce individual risk of predation in shorebirds (Cresswell, 1994). Plovers were often observed in mixed flocks with Western sandpiper, Calidris mauri, and least sandpiper, Caladris minutilla. Both species often form flocks greater than 100 individuals, and frequently murmurate, both spontaneously and when approached by predators. As a result, there were many more sandpipers than plovers in the flock, and they were much more conspicuous due to their behavior. Thus, forming mixed flocks may have lowered the predation risk for plovers, which may need to spend most of their time foraging and exposed to predators. In addition to the advantages of flocking behavior, plovers also appeared to select for habitat that increased crypsis. Many of the plover sightings during the second season occurred at E14 within newly placed oyster shell plots. Past studies have indicated that, during the breeding season, plovers select oyster shell plots over nonshelled habitat, especially newly created shell plots (SFBBO, 2013). Older shell plots tend to become silted over and gray colored due to seasonal flooding, losing much of their value to hide plovers, whereas fresh shell plots are bright white and maximize 
crypsis. However, further research is needed to determine if wintering plovers do in fact select for oyster shell habitat.

Plover prey size may also assist in predator avoidance. The invertebrates collected during this study suggest that the average size of prey available to plovers was quite small. Foraging for smaller prey has been shown to be a strategy to reduce predation risk, as the shorter handling time allows for increased vigilance (Thompson, 1983). Although overall size of prey was small, this study did show that plovers selected for sites with significantly larger invertebrates at plover present compared to plover absent sites. This may represent a balance between foraging benefit and predation risk.

\section{Plover Origin}

The observational component of this study also contributed to the current understanding of plover winter migration. Banded birds play an important role in determining the source of winter migrants (Page et. al., 1986). Plovers are known to migrate often between Recovery Unit 4, encompassing the Monterey Bay and San Mateo Coast, and Recovery Unit 3, due to the close proximity of the areas (B. Pearl, pers obs). Oregon birds have been documented wintering from Northern California to Baja Sur California (Page, Stern, \& Paton, 1995). Plovers from Utah wintering in Northern California, however, have not been documented, and has only been documented several times recently in Central and Southern California (Frances Bidstrup, pers. comm). Utah birds normally winter in Mexico, traveling a minimum of 1,104 km from the Great Salt Lake to reach wintering grounds (Page, Stern, \& Paton, 1995). Meanwhile, the distance from the Great Salt Lake to the San Francisco Bay is $970 \mathrm{~km}$. It is possible that Utah 
plovers have wintered in the past in the San Francisco Bay, but went undetected due to the relative lack of winter research conducted in the area. Although these findings can't determine if Utah plovers have been using the San Francisco Bay for wintering, it may indicate changes to their normal wintering habitat in Mexico.

It may be that plovers observed on the salt ponds were also visitors from interior California, but research is needed to confirm this. Page et al. (1986) found that 6 of 86 females banded at Mono Lake wintered along the coast at such disparate locations as Del Monte Beach, Devereaux Beach, Goleta Beach, Malibu Lagoon, and San Clemente Island. Without an increase in banding in the South Bay and interior population in combination with increased band searching efforts, however, it will not be possible to identify the source of most of the wintering plovers. 


\section{Management and Conservation Implications}

\section{Recommendations}

The findings of this study indicate several recommendations for land managers that could create more favorable wintering conditions for plovers. First, increased efforts should be made to remove perches located within $200 \mathrm{~m}$ from ponds known to be important to plovers. There are numerous hunting blinds, posts, and poles found throughout the South Bay, and these create ideal perches for predators such as peregrine falcons, red tailed hawks, and corvids. Since my findings showed that plovers tended to avoid these perches, removing them would create larger areas for plovers to forage and roost, as well as reduce overall predation risk in the pond area.

Since plovers were shown to select for areas with increasing water cover, land managers can create more favorable pond conditions by adjusting water control structures appropriately. Plover present sites averaged $2-5 \mathrm{~cm}$ of water depth and $17 \%$ water cover. Reproducing these conditions would require opening control structures to allow water to briefly cover sections of ponds. By doing so, the ponds would have large amounts of shallow water cover, which appears to be a feature attracting plovers, as it creates foraging habitat.

Lastly, while dense and tall stands of vegetation should not be allowed to proliferate, small stands of vegetation under $10 \mathrm{~cm}$ spaced intermittently throughout the ponds should be tolerated. Plovers appeared to select for these areas, though the exact reason is unclear. Appropriate places to allow vegetation must be determined on a pondby-pond basis. 


\section{Future Research}

In order to better understand the prey availability of wintering Snowy Plovers in the South Bay salt ponds, additional research should examine invertebrates found within salt pond soil at an appropriate depth for plover foraging. In addition, invertebrate collection and identification at tidal flats where plovers forage would help fill in the gap of how plovers are fulfilling their energetic needs during winter. These findings could provide additional management direction that would benefit plovers and other shorebirds using the mostly dry salt ponds. Furthermore, efforts should be made to collect and analyze plover feces to determine definitively what plovers are foraging upon, in addition to information on available prey items.

Increased knowledge of plover winter migration is needed to better understand and protect populations during this important time. Thus, increased band resighting and banding efforts in South Bay salt ponds during the wintering season would greatly assist in the ability to track movement of plovers throughout their range. This information could then be used to determine where to restore and enhance habitat for plover foraging, and aid in prediction of population dynamics for various populations throughout the range. 


\section{References}

Altmann, J. (1974). Observational study of behavior: Sampling methods. Behaviour, 49, 227-266.

Alves, J. A., Gunnarsson, T. G., Hayhow, D. B., Appleton, G. F., Potts, P. M., Sutherland, W. J., \& Gill, J. A. (2013). Costs, benefits, and fitness consequences of different migratory strategies. Ecology, 94, 11-17.

Amat, J., \& Masero, J. (2004). Predation risk on incubating adults constrains the choice of thermally favourable nest sites in a plover. Animal Behaviour, 67, 293-300. doi: 10.1016/j.anbehav.2003.06.014

Anteau, M. J., \& Sherfy, M. H. (2010). Diurnal variation in invertebrate catch rates by sticky traps: Potential for biased indices of piping plover forage. Wetlands, 30, $757-$ 762.

Armitage, A. R., Jensen, S. M., Yoon, J. E., \& Ambrose, R. F. (2007). Wintering shorebird assemblages and behavior in restored tidal wetlands in southern California. Restoration Ecology, 15, 139-148.

Athearn, N. D., Takekawa, J. Y., Jaffe, B., Hattenbach, B. J., \& Foxgrover, A. C. (2010). Mapping elevations of tidal wetland restoration sites in San Francisco bay: Comparing accuracy of aerial LiDAR with a singlebeam echosounder. Journal of Coastal Research, 26, 312-319.

Athearn, N. D., Takekawa, J. Y., Bluso-Demers, J. D., Shinn, J. M., Brand, L. A., Robinson-Nilsen, C. W., \& Strong, C. M. (2012). Variability in habitat value of commercial salt production ponds: Implications for waterbird management and tidal marsh restoration planning. Hydrobiologia, 697, 139-155. doi: 10.1007/s10750-012$1177-y$

Barbour, M. G., de Jong, T. M., \& Johnson, A. F. (1976). Synecology of beach vegetation along the pacific coast of the united states of america: A first approximation. Journal of Biogeography, 3, 55-69.

Bond, A. B. (1980). Optimal foraging in a uniform habitat: the search mechanism of the green lacewing. Animal Behaviour, 28, 10-19.

Brew, D. S., \& Williams, P. B. (2010). Predicting the impact of large-scale tidal wetland restoration on morphodynamics and habitat evolution in South San Francisco Bay, California. Journal of Coastal Research, 26, 912-924. 
Brindock, K. M., \& Colwell, M. A. (2011). Habitat selection by western snowy plovers during the nonbreeding season. Journal of Wildlife Management, 75, 786-793. doi: 10.1002/jwmg.106

Catlin, D. H., Fraser, J. D., Felio, J. H., \& Cohen, J. B. (2011). Piping plover habitat selection and nest success on natural, managed, and engineered sandbars. Journal of Wildlife Management, 75, 305-310.

California Department of Fish and Wildlife. (2010). Species detail for western snowy plover. Retrieved March 11, 2013, from https://nrm.dfg.ca.gov/taxaquery/SpeciesDetail.aspx?taxonid=1166\&PTitle=western + snowy + plover\&STitle $=$ Charadrius + alexandrinus + nivosus

California Department of Fish and Wildlife. (2013). Threatened and endangered birds. Retrieved April 30, 2013, from http://www.dfg.ca.gov/wildlife/nongame/t_e_spp/bird.html

Casazza, M. L., Ricca, M. A., Overton, C. T., Takekawa, J. Y., Merritt, A. M., \& Ackerman, J. T. (2014). Dietary mercury exposure to endangered California clapper rails in san francisco bay. Marine Pollution Bulletin, 86, 254-260.

Castro, M., Masero, J. A., Perez-Hurtado, A., Amat, J. A., \& Megina, C. (2009). Sexrelated seasonal differences in the foraging strategy of the kentish plover. Condor, $111,624-632$.

Colwell, M. A., \& Landrum, S. L. (1993). Nonrandom shorebird distribution and finescale variation in prey abundance. Condor, 95, 94-103. doi:10.2307/1369390

Colwell, M.A., Burrell, N.S., Hardy, M.A., Kayano, K., Muir, J.J., Pearson, W.J., Peterson, S.A., \& Sesser, K.A. (2010). Arrival times, laying dates, and reproductive success of snowy plovers in two habitats in coastal northern California. Journal of Field Ornithology, 81, 349-360.

Colwell, M.A., Meyer, J.J., Hardy, M.A., Mcallister, S.E., Transou, A.N., Levalley, R. R., \& Dinsmore, S.J. (2011). Western snowy plovers Charadrius alexandrinus nivosus select nesting substrates that enhance egg crypsis and improve nest survival. Ibis, 153, 303-311.

Conover, M.R., \& Conover, D.O. (1981). A documented history of ring-billed gull and California gull colonies in the western United States. Colonial Waterbirds, 4, 37-43.

Conover, M.R. (1983). Recent changes in ring-billed and California gull populations in the western United States. Wilson Journal of Ornithology, 95, 362-383. 
Conway, W. C., Smith, L. M., \& Ray, J. D. (2005). Shorebird habitat use and nest-site selection in the playa lakes region. Journal of Wildlife Management, 69, 174-184.

Cresswell, W. (1994). Flocking is an effective anti-predation strategy in redshanks, Tringa totanus. Animal Behaviour, 47, 433-442.

Cresswell, W., \& Whitfield, D. (1994). The effects of raptor predation on wintering wader populations at the Tyninghame estuary, southeast Scotland. Ibis, 136, 223232. doi: 10.1111/j.1474-919X.1994.tb01088.x

Cresswell, W. (2008). Non-lethal effects of predation in birds. Ibis, 150, 3-17.

Crooks, K.R., \& Soulé, M.E. (1999). Mesopredator release and avifaunal extinctions in a fragmented system. Nature, 400, 563-566.

Daan, S., Dijkstra, C., Drent, R., \& Meijer, T. (1988). Food supply and the annual timing of avian reproduction. In Proceedings of the International Ornithological Congress (Vol. 19, pp. 392-407). Ottawa: University of Ottawa Press

Danufsky, T., \& Colwell, M. A. (2003). Winter shorebird communities and tidal flat characteristics at Humboldt Bay, California. The Condor, 105, 117-129.

DeBenedictis, P. A., Gill, F. B., Hainsworth, F. R., Pyke, G. H., \& Wolf, L. L. (1978). Optimal meal size in hummingbirds. American Naturalist, 112, 301-316.

Dekker, D., \& Ydenberg, R. (2004). Raptor predation on wintering dunlins in relation to the tidal cycle. Condor, 106, 415-419. doi: 10.1650/7364

Demers, S.A., \& Robinson-Nilsen, C.W. (2012). Monitoring western snowy plover nests with remote surveillance systems in San Francisco Bay, California. Journal of Fish and Wildlife Management, 3, 123-132. doi: 10.3996/062011-JFWM-036

Drake, K. R., Thompson, J. E., Drake, K. L., \& Zonick, C. (2001). Movements, habitat use, and survival of nonbreeding piping plovers. The Condor, 103, 259-267.

Dugan, P., Evans, P., Goodyer, L., \& Davidson, N. (1981). Winter fat reserves in shorebirds: Disturbance of regulated levels by severe weather conditions. Ibis, 123, 359-363.

Galbraith, H., Jones, R., Park, R., Clough, J., Herrod-Julius, S., Harrington, B., \& Page, G. (2002). Global climate change and sea level rise: potential losses of intertidal habitat for shorebirds. Waterbirds, 25, 173-183. 
Goals Project (2000). Baylands Ecosystem Species and Community Profiles: Life histories and environmental requirements of key plants, fish and wildlife. Prepared by the San Francisco Bay Area Wetlands Ecosystem Goals Project. P.R. Olofson, editor. San Francisco Bay Regional Water Quality Control Board, Oakland, Calif.

Goss-Custard, J. (1977). Optimal foraging and the size selection of worms by redshank, Tringa totanus, in the field. Animal Behaviour, 25, 10-29.

Goss-Custard, J. D., West, A. D., Yates, M. G., Caldow, R. W., Stillman, R. A., Bardsley, L., Castilla, J., Castro, M., Dierschke, V., \& Eichhorn, G. (2006). Intake rates and the functional response in shorebirds (Charadriiformes) eating macroinvertebrates. Biological Reviews, 81, 501-529.

Hartig, E. K., Gornitz, V., Kolker, A., Mushacke, F., \& Fallon, D. (2002). Anthropogenic and climate-change impacts on salt marshes of Jamaica Bay, New York City. Wetlands, 22, 71-89.

Howe, M. A. (1987). Wetlands and waterbird conservation. American Birds, 41, 204-209.

Hudgens, B.H., Eberhart-Phillips, L., Stenzel, L., Burns, C., Colwell, M., \& Page, G. (2014). Population Viability Analysis of the Western Snowy Plover. Report prepared for the U.S. Fish and Wildlife Service. Arcata, CA.

Kilham, L. (1984). American crows robbing great egrets and white ibis of large, eel-like salamanders. Colonial Waterbirds, 7, 143-145.

Krebs, J. R., Ryan, J. C., \& Charnov, E. L. (1974). Hunting by expectation or optimal foraging? A study of patch use by chickadees. Animal Behaviour, 22, 953-964.

Lafferty, K. (2001). Disturbance to wintering western snowy plovers. Biological Conservation, 101, 315-325. doi: 10.1016/S0006-3207(01)00075-1

Lima, S. L. (1986). Predation risk and unpredictable feeding conditions: Determinants of body mass in birds. Ecology, 67, 377-385.

Martin, T. E. (1987). Food as a limit on breeding birds: a life-history perspective. Annual Review of Ecology and Systematics, 18, 453-487.

McNamara, J. M., \& Houston, A. I. (1990). The value of fat reserves and the tradeoff between starvation and predation. Acta Biotheoretica, 38, 37-61.

Meire, P., \& Ervynck, A. (1986). Are oystercatchers (Haematopus ostralegus) selecting the most profitable mussels (Mytilus edulis)? Animal Behaviour, 34, 1427-1435. 
Metcalfe, N., \& Furness, R. (1984). Changing priorities: The effect of pre-migratory fattening on the trade-off between foraging and vigilance. Behavioral Ecology and Sociobiology, 15, 203-206.

Metropolitan Transportation Association, \&Association of Bay Area Governments. (2010.) Bay Area Census 2010. Retrieved from http://www.bayareacensus.ca.gov/

Norris, D. R., Marra, P. P., Kyser, T. K., Sherry, T. W., \& Ratcliffe, L. M. (2004). Tropical winter habitat limits reproductive success on the temperate breeding grounds in a migratory bird. Proceedings of the Royal Society of London. Series B: Biological Sciences, 271, 59-64.

Obrebsky, S \& Irwin, G. (2001). Amphipod (Traskorchestia traskiana) - Pickleweed (Salicornia virginica) Interactions in San Francisco Bay Salt Marshes. CALFED proposal.

Page, G. W., Bidstrup, F. C., Ramer, R. J., \& Stenzel, L. E. (1986). Distribution of wintering snowy plovers in California and adjacent states. Western Birds, 17, 145170 .

Page, G. W., Stern, M. A., \& Paton, P. W. (1995). Differences in wintering areas of snowy plovers from inland breeding sites in western north america. Condor, 97, 258262.

Page, G.W., Stenzel, L., Winkler, D., \& Swarth, C. (1983). Spacing out at mono lake breeding success, nest density, and predation in the snowy plover. Auk, 100, 13-24.

Page, G.W., Stenzel, L., Warriner, J.S., Warriner, J.C. \& Paton, P.W. (2009). Snowy Plover (Charadrius nivosus), The Birds of North America Online (A. Poole, Ed.). Ithaca: Cornell Lab of Ornithology; Retrieved from the Birds of North America Online: http://bna.birds.cornell.edu/bna/species/154. doi:10.2173/bna.154

Page, G.W., \& Stenzel, L.E., (1981). The breeding status of the snowy plover in California. Western Birds. 12, 1-40.

Page, G., \& Whitacre, D. F. (1975). Raptor predation on wintering shorebirds. Condor, 77, 73-83.

Perkins, A., Whittingham, M., Bradbury, R., Wilson, J., Morris, A., \& Barnett, P. (2000). Habitat characteristics affecting use of lowland agricultural grassland by birds in winter. Biological Conservation, 95, 279-294. doi:10.1016/S0006-3207(00)00042-2

Quammen, M. (1982). Influence of subtle substrate differences on feeding by shorebirds on intertidal mudflats. Marine Biology, 71, 339-343. 
Robinson, C. W. (2008). Western snowy plover use of managed salt ponds at Eden Landing, Hayward, CA. (Master's thesis). San Jose State University, San Jose, CA.

Robinson-Nilsen, C.W., Bluso Demers, J. \& Strong, C. (2011). Western snowy plovers nesting success, fledging success and avian predator surveys in the San Francisco Bay, 2011. Retrieved 03,07, 2013, from http://www.fws.gov/arcata/es/birds/WSP/documents/siteReports/California/RU3_SN PL_Report_2011.pdf

Saalfeld, S. T., Conway, W. C., Haukos, D. A., \& Johnson, W. P. (2011). Nest success of snowy plovers (Charadrius nivosus) in the southern high plains of Texas. Waterbirds, 34, 389-399.

Saino, N., Szép, T., Ambrosini, R., Romano, M., \& Moller, A. (2004). Ecological conditions during winter affect sexual selection and breeding in a migratory bird. Proceedings-Royal Society of London b, 271, 681-686.

San Francisco Bay Bird Observatory. (2003). Western Snowy Plover Breeding Season Surveys for 2003. Alviso, CA:, Strong, C., \& Dakin, R.

San Francisco Bay Bird Observatory. (2004). Western Snowy Plover Numbers, Nesting Success, and Avian Predator Surveys in the San Francisco Bay, 2004. Alviso, CA: Strong, C., Wilson, N.R., \& Albertson, J.

San Francisco Bay Bird Observatory. (2005). Western Snowy Plover Population, Nesting Success, and Predator Surveys in the San Francisco Bay - 2005 Breeding Season. Alviso, CA:, Tucci, L., Strong, C., \& Albertson, J.

San Francisco Bay Bird Observatory. (2006). Western Snowy Plover Numbers, Nesting Success, and Avian Predator Surveys in the San Francisco Bay, 2006. Alviso, CA: Robinson, C.W., Strong, C., Tucci, L., \& Albertson, J.

San Francisco Bay Bird Observatory. (2007). Western Snowy Plover Numbers, Nesting Success, and Avian Predator Surveys in the San Francisco Bay, 2007. Milpitas, CA: Le Fer, D., Robinson, C.W., Albertson, J. \& Strong, C.

San Francisco Bay Bird Observatory. (2008). Western Snowy Plover Numbers, Nesting Success, Fledging Success and Avian Predator Surveys in the San Francisco Bay, 2008. Milpitas, CA: Bluso Demers, J., Robinson-Nilsen, C.W., \& Strong, C.

San Francisco Bay Bird Observatory. (2009). Western Snowy Plover Numbers, Nesting Success, Fledging Success and Avian Predator Surveys in the San Francisco Bay, 2009. Milpitas, CA: Bluso Demers, J., Robinson-Nilsen, C.W., \& Strong, C. 
San Francisco Bay Bird Observatory. (2010). Western Snowy Plover Numbers, Nesting Success, Fledging Success and Avian Predator Surveys in the San Francisco Bay, 2010. Milpitas, CA: Bluso Demers, J., Robinson-Nilsen, C.W., \& Strong, C.

San Francisco Bay Bird Observatory. (2011). Western Snowy Plover Numbers, Nesting Success, Fledging Success and Avian Predator Surveys in the San Francisco Bay, 2011. Milpitas, CA: Bluso Demers, J., Robinson-Nilsen, C.W., \& Strong, C.

San Francisco Bay Bird Observatory. (2012). Western Snowy Plover Monitoring in the San Francisco Bay Annual Report 2012. Milpitas, CA: Donehower, C., Tokatlian, K., Robinson-Nilsen, C.W., \& Strong, C.

San Francisco Bay Bird Observatory. (2013). Western Snowy Plover Monitoring in the San Francisco Bay Annual Report 2013. Milpitas, CA: Robinson-Nilsen, C., Tokatlian, K., Scullen, J., \& Burns, C.

San Francisco Bay Bird Observatory. (2014). Western Snowy Plover Monitoring in the San Francisco Bay Annual Report 2014. Milpitas, CA: Tokatlian, K., Scullen, J., \& Burns, C.

San Francisco Bay Bird Observatory. (2015). Western Snowy Plover Monitoring in the San Francisco Bay Annual Report 2015. Milpitas, CA: Pearl, B., Tokatlian, K., \& Scullen, J.

Scaps, P. (2002). A review of the biology, ecology and potential use of the common ragworm hediste diversicolor (OF müller)(annelida: Polychaeta). Hydrobiologia, 470(1), 203-218.

Shochat, E., Lerman, S. B., Anderies, J. M., Warren, P. S., Faeth, S. H., \& Nilon, C. H. (2010). Invasion, competition, and biodiversity loss in urban ecosystems. Bioscience, 60, 199-208.

Solek, C. W., Sutula, M. A., Stein, E. D., Roberts, C., Clark, R., O'Connor, K., \& Ritter, K. J. (2011). Determining the health of California's coastal salt marshes using rapid assessment. (Technical Report No. 0701). Costa Mesa, CA: Southern California Coastal Water Research Project.

South Bay Salt Pond Restoration Project. (2007). Adaptive Management Plan. Retrieved August 2014 from http://www.southbayrestoration.org/pdf_files/SBSP_EIR_Final/Appendix D Final AMP.pdf

South Bay Salt Pond Restoration Project. (n.d.) Track our progress. Retrieved February 2013 from http://www.southbayrestoration.org/track-our-progress/index.html\#eden 
Stralberg, D., Cameron, D. R., Reynolds, M. D., Hickey, C. M., Klausmeyer, K., Busby, S. M., Stenzel, L.E., Shuford, D.W., \& Page, G. W. (2011). Identifying habitat conservation priorities and gaps for migratory shorebirds and waterfowl in California. Biodiversity and Conservation, 20, 19-40. doi: 10.1007/s10531-0109943-5

Strong, C., Spear, L., Ryan, T., \& Dakin, R. (2004). Forster's tern, Caspian tern, and California gull colonies in San Francisco Bay: Habitat use, numbers and trends, 1982-2003. Waterbirds, 27, 411-423. doi: 10.1675/15244695(2004)027[0411:FTCTAC]2.0.CO;2

Sutherland, W. J. (1982). Do oystercatchers select the most profitable cockles? Animal Behaviour, 30, 857-861.

Takekawa, J.Y., Lu, C.T., \& Pratt, R.T. (2001). Avian communities in baylands and artificial salt evaporation ponds of the San Francisco Bay estuary. Hydrobiologia, $466,317-328$.

Thompson, D. B. A., \& Barnard, C. J. (1984). Prey selection by plovers: optimal foraging in mixed-species groups. Animal behaviour, 32, 554-563.

Thompson, D. (1983). Prey assessment by plovers (charadriidae): Net rate of energy intake and vulnerability to kleptoparasites. Animal Behaviour, 31, 1226-1236.

Trulio, L., Robinson-Nilsen, C., Sokale, J., \& Lafferty, K. D. (2012). Report on nesting snowy plover response to new trail use in the South Bay Salt Pond Restoration Project. (Technical Document). South Bay Salt Pond Restoration Project.

United States Fish and Wildlife Services. (2002). Western snowy plover, Charadrius alexandrinus nivosus, life history. Retrieved March 11, 2013, from http://ecos.fws.gov/docs/life_histories/B07C.html

United States Fish and Wildlife Service. (2013). Species reports: Listed animals vertebrates, invertebrates. Retrieved April 30, 2013, from http://ecos.fws.gov/tess_public/pub/listedAnimals.jsp

Van Den Hout, Piet J, Spaans, B., \& Piersma, T. (2008). Differential mortality of wintering shorebirds on the Banc d'Arguin, Mauritania, due to predation by large falcons. Ibis, 150, 219-230.

Watson, E. B. (2004). Changing elevation, accretion, and tidal marsh plant assemblages in a south san francisco bay tidal marsh. Estuaries, 27, 684-698. 
Webb, E. B., Smith, L. M., Vrtiska, M. P., \& Lagrange, T. G. (2010). Effects of local and landscape variables on wetland bird habitat use during migration through the rainwater basin Journal of Wildlife Management, 74, 109-119. doi:10.2193/2008577

Williams, P., \& Faber, P. (2001). Salt marsh restoration experience in San Francisco Bay. Journal of Coastal Research, 27, 203-211.

Williams, D. D., \& Williams, N. E. (1998). Aquatic insects in an estuarine environment: densities, distribution and salinity tolerance. Freshwater Biology, 39, 411-421.

Wrege, P. H., David Shuford, W., Winkler, D. W., \& Jellison, R. (2006). Annual variation in numbers of breeding California gulls at Mono Lake, California: The importance of natal philopatry and local and regional conditions. The Condor, 108, $82-96$.

Ydenberg, R., Butler, R., Lank, D., Smith, B., \& Ireland, J. (2004). Western sandpipers have altered migration tactics as peregrine falcon populations have recovered. Proceedings of the Royal Society B-Biological Sciences, 271, 1263-1269. doi: 10.1098/rspb.2004.2713

Zuria, I., \& Mellink, E. (2005). Fish abundance and the 1995 nesting season of the Least Tern at Bahía de San Jorge, Northern Gulf of California, México. Waterbirds, 28, 172-180. 


\section{Appendices}

Appendix 1. Color band resighting list. The combination is read top to bottom on the left leg, followed by top to bottom on the right leg

\begin{tabular}{|l|l|l|l|l|l|}
\hline Date & Pond & Combo & Origin & Band Date & Sex \\
\hline $12 / 19 / 14$ & E14 & KO:PR & SFBBO & $8 / 7 / 13$ & Female \\
\hline $12 / 29 / 14$ & E13 & KW:OY & Utah & Unknown & Unknown \\
\hline $12 / 31 / 14$ & E13 & B:BY & Unknown & Unknown & Male \\
\hline $1 / 6 / 15$ & E13 & ON:BW & SFBBO & $8 / 2 / 14$ & Male \\
\hline $1 / 6 / 15$ & E13 & KO:RR & SFBBO & $6 / 4 / 14$ & Male \\
\hline $1 / 6 / 15$ & E12 & G/Y/G:Y & Oregon & $5 / 25 / 13$ & Unknown \\
\hline $1 / 6 / 15$ & E12 & G/W/G:L & Oregon & Unknown & Unknown \\
\hline $1 / 7 / 15$ & E13 & ON:OB & SFBBO & $8 / 22 / 14$ & Male \\
\hline $1 / 23 / 15$ & RSF2 & GK:PW & SFBBO & $7 / 16 / 14$ & Unknown \\
\hline $1 / 29 / 15$ & E14 & G/Y/G:L & Oregon & Unknown & Unknown \\
\hline $1 / 29 / 15$ & E14 & KO:PR & SFBBO & $8 / 7 / 13$ & Female \\
\hline $2 / 3 / 15$ & E14 & GK:YB & SFBBO & $7 / 18 / 14$ & Male \\
\hline $2 / 3 / 15$ & E14 & KY:WG & Utah & Unknown & Unknown \\
\hline $2 / 3 / 15$ & E14 & G/Y/G:Y & Oregon & $5 / 25 / 13$ & Unknown \\
\hline $2 / 3 / 15$ & E14 & ON:WG & Unknown & Unknown & Unknown \\
\hline $2 / 3 / 15$ & E14 & LP:YL & Unknown & Unknown & Unknown \\
\hline $2 / 3 / 15$ & E14 & GK:BB & SFBBO & $8 / 16 / 10$ & Male \\
\hline $2 / 3 / 15$ & E14 & G/Y/G:V & Oregon & $6 / 14 / 14$ & Unknown \\
\hline $2 / 12 / 15$ & E14 & KO:WG & SFBBO & $6 / 10 / 14$ & Unknown \\
\hline $2 / 17 / 15$ & E14 & ON:WG & Unknown & Unknown & Unknown \\
\hline $2 / 17 / 15$ & E14 & AP:YA & Mont. Bay Aqua. & $5 / 6 / 14$ & Male \\
\hline $2 / 17 / 15$ & E14 & RK:WG & SFBBO & $7 / 13 / 08$ & Male \\
\hline $2 / 18 / 15$ & E14 & ON:AR & SFBBO & $7 / 10 / 14$ & Female \\
\hline $2 / 18 / 15$ & E14 & WK:PB & Utah & Unknown & Unknown \\
\hline $2 / 19 / 15$ & E14 & ON:OG & SFBBO & $7 / 24 / 14$ & Male \\
\hline $2 / 19 / 15$ & E14 & RK:WG & SFBBO & Unknown & Unknown \\
\hline $2 / 19 / 15$ & E14 & KW:OW & Utah & $5 / 23 / 14$ & Unknown \\
\hline $2 / 24 / 15$ & A22 & RO:RW & Pajaro Spit & $7 / 26 / 13$ & Unknown \\
\hline $2 / 24 / 15$ & E14 & KO:BR & SFBBO & & \\
\hline
\end{tabular}

